\title{
Follicular Helper T Cells in Systemic Lupus Erythematosus: Why Should They Be Considered as Interesting Therapeutic Targets?
}

\author{
Matthieu Sawaf, Hélène Dumortier, and Fanny Monneaux \\ CNRS, Immunopathologie et Chimie Thérapeutique/Laboratory of Excellence MEDALIS, \\ Institut de Biologie Moléculaire et Cellulaire, 67084 Strasbourg, France
}

Correspondence should be addressed to Fanny Monneaux; f.monneaux@unistra.fr

Received 4 May 2016; Revised 6 July 2016; Accepted 17 July 2016

Academic Editor: Takashi MaruYama

Copyright (C) 2016 Matthieu Sawaf et al. This is an open access article distributed under the Creative Commons Attribution License, which permits unrestricted use, distribution, and reproduction in any medium, provided the original work is properly cited.

Systemic lupus erythematosus (SLE) is a chronic autoimmune disease characterized by B cell hyperactivity leading to the production of autoantibodies, some of which having a deleterious effect. Reducing autoantibody production thus represents a way of controlling lupus pathogenesis, and a better understanding of the molecular and cellular factors involved in the differentiation of B cells into plasma cells could allow identifying new therapeutic targets. Follicular helper T cells $\left(\mathrm{T}_{\mathrm{FH}}\right)$ represent a distinct subset of CD4 ${ }^{+} \mathrm{T}$ cells specialized in providing help to B cells. They are required for the formation of germinal centers and the generation of longlived serological memory and, as such, are suspected to play a central role in SLE. Recent advances in the field of $\mathrm{T}_{\mathrm{FH}}$ biology have allowed the identification of important molecular factors involved in $\mathrm{T}_{\mathrm{FH}}$ differentiation, regulation, and function. Interestingly, some of these $\mathrm{T}_{\mathrm{FH}}$-related molecules have been described to be dysregulated in lupus patients. In the present review, we give an overview of the aberrant expression and/or function of such key players in lupus, and we highlight their potential as therapeutic targets.

\section{Introduction}

Systemic lupus erythematosus (SLE) is a severe systemic autoimmune disease and, as such, is characterized by a loss of self-tolerance. The etiology of SLE is not well defined, but genetic, hormonal, and environmental factors, as well as immune disorders, are likely implicated. During SLE, inflammation leads to damage of various tissues, including the joints, skin, kidneys, heart, lungs, blood vessels, and brain. Dysregulation of various components of the immune system can be observed at different stages of disease development, but hyperactivity of B cells, leading to excessive production of multiple autoantibodies (autoAb), is one of the major immunological stigmata of SLE. Indeed, SLE is characterized by the production of antinuclear auto Ab (e.g., autoAb specific for chromatin) and by the formation of immune complexes, which contribute to tissue damage. Deposits of immune complexes in organs such as kidneys lead to subsequent inflammation through the activation of the complement system and the recruitment of inflammatory cells. The presence of auto $\mathrm{Ab}$ is an absolute prerequisite for the development of lupus nephritis [1] and, interestingly, we demonstrated that pathogenic autoAb can be locally produced by plasma cells, which have homed to inflamed kidneys of lupus mice [2]. $B$ cells and derivatives (plasma cells) are thus considered at the center of SLE pathogenesis and this is supported by the observation of a high frequency of plasma cell precursors in the blood of children with SLE [3]. Furthermore, an increase of circulating plasma cells in lupus patients is correlated with disease activity [4].

The generation of $\mathrm{Ab}$ can occur via the extrafollicular or the germinal center (GC) responses. The extrafollicular response leads to short-lived plasma cells, which do not go through the affinity maturation process. In contrast, the GC is the theater of intense cell collaboration between GC $B$ cells and follicular helper $T$ cells $\left(\mathrm{T}_{\mathrm{FH}}\right)$ leading to the differentiation of long-lived plasma cells harboring high antigen-specificity. Interestingly, lupus auto Ab are high affinity, somatically mutated, and class-switched immunoglobulin (Ig)G [5] indicating T and B cell collaboration [6] and intense GC activity. Therefore, it is likely that a dysfunction in B cell differentiation mechanisms occurs in lupus, leading to 
excessive numbers of autoreactive plasma cells. It is particularly attracting and plausible to envisage that a dysregulation of $\mathrm{T}_{\mathrm{FH}}$ could be the underlying key factor.

In this review, we succinctly expose recent understanding in $\mathrm{T}_{\mathrm{FH}}$ biology (described in detail elsewhere; see [7] for review), in order to introduce important molecular factors involved in $\mathrm{T}_{\mathrm{FH}}$ differentiation, regulation, and function. We then give an overview of the aberrant expression and/or function of such key players in lupus patients, and we highlight their potential as therapeutic targets.

\section{2. $T_{\mathrm{FH}}$ Cells: From Their Generation to Their Regulation}

The generation of high affinity $\mathrm{Ab}$ requires $\mathrm{T} / \mathrm{B}$ interactions that mainly occur in GC. $\mathrm{T}_{\mathrm{FH}}$ cells represent a distinct subset of $\mathrm{CD}^{+} \mathrm{T}$ cells involved in GC formation and specialized in providing help to B cells to differentiate into plasma cells or memory $\mathrm{B}$ cells [8]. $\mathrm{T}_{\mathrm{FH}}$ express high levels of $\mathrm{CXC}$ chemokine receptor type 5 (CXCR5), PD-1 (Programmed Death-1), ICOS (Inducible T cell CO-Stimulator), and the regulator transcription factor Bcl6 (B cell lymphoma 6), which provide excellent markers for their identification. Moreover, secretion of high levels of IL-21 is a critical characteristic of $\mathrm{T}_{\mathrm{FH}}$ cells.

$\mathrm{T}_{\mathrm{FH}}$ are generated after immunization or infection following the interaction of naive $\mathrm{CD} 4^{+} \mathrm{T}$ cells with dendritic cells (DC) within the T cell zone of secondary lymphoid organs (SLO). Signals provided by DC induce the expression of a myriad of proteins (transcription factors, surface molecules, and cytokines) that are essential for $\mathrm{T}_{\mathrm{FH}}$ generation, migration, and function. In fact, $\mathrm{T}_{\mathrm{FH}}$ differentiation is a multistage process (Figure 1), which can be sequentially defined as follows: (i) naive $\mathrm{CD} 4^{+} \mathrm{T}$ cells are activated by $\mathrm{DC}$ (thanks to the MHC-peptide complex/TCR interaction) in the T cell zone and become immature $\mathrm{T}_{\mathrm{FH}}$ (also called pre- $\mathrm{T}_{\mathrm{FH}}$ ) [9]; (ii) newly generated pre- $\mathrm{T}_{\mathrm{FH}}$ then migrate to the interfollicular zone, where cognate interactions with $\mathrm{B}$ cells allow the final maturation step; (iii) these mature $\mathrm{T}_{\mathrm{FH}}$ reach the $\mathrm{GC}$ in which $\mathrm{T}_{\mathrm{FH}}-\mathrm{GC} \mathrm{B}$ cell interactions will favor isotype class switch, somatic hypermutations, and affinity maturation.

2.1. Pre- $T_{F H}$ Generation: $D C$ as the Stage Director. The initial priming of $\mathrm{CD}^{+} \mathrm{T}$ cells requires cognate interactions and costimulatory signals delivered by DC through CD40, CD80/86, ICOSL, and OX40L (Table 1). CD28 (that binds CD80/86) was shown to be essential to $\mathrm{T}_{\mathrm{FH}}$ development as mice deficient for CD28 display $\mathrm{CD}^{+}{ }^{+} \mathrm{T}$ cells that fail to upregulate CXCR5 and OX40, leading to disrupted GC formation [10]. In addition, upregulation of OX40L on DC following CD40-induced maturation allows CXCR5 expression by $\mathrm{OX} 40^{+} \mathrm{T}$ cells [11]. Moreover, ICOS signaling leads to an increased expression of the transcription factors Bcl6 and Ascl2 (achaete-scute homologue-2). The latter promote both the reciprocal CXCR5 upregulation and CCR7 downregulation on activated $\mathrm{CD} 4^{+} \mathrm{T}$ cells, which then become pre- $\mathrm{T}_{\mathrm{FH}}$ $[12,13]$. In turn, Bcl6 induces the expression of ICOS, PD1,
CD40L, and SAP (SLAM- (Signaling Lymphocytic Activation Molecule-) Associated Protein; critical for T-B interaction).

Cytokines secreted by DC also play a pivotal role in pre$\mathrm{T}_{\mathrm{FH}}$ development (Table 1). IL-6, a DC-derived proinflammatory cytokine, has been demonstrated to be the main soluble factor driving $\mathrm{T}_{\mathrm{FH}}$ differentiation in mice [14]. In humans, IL-12 has been shown to be the key cytokine that promotes $\mathrm{T}_{\mathrm{FH}}$-like cell differentiation $[15,16]$. If, in the initial work, neither IL-6 nor IL-21 were described as being able to promote $\mathrm{T}_{\mathrm{FH}}$ differentiation [15], a recent study suggests that human plasmablasts produce IL-6, which is responsible for the subsequent differentiation of naive $\mathrm{CD} 4^{+} \mathrm{T}$ cells into $\mathrm{B}$ cell helpers $\mathrm{CXCR}^{+} \mathrm{ICOS}^{+} \mathrm{Bcl} 6^{+} \mathrm{IL}-21^{+} \mathrm{T}$ cells [17]. IL-21 is required for $\mathrm{T}_{\mathrm{FH}}$ function but it is also an important factor for $\mathrm{T}_{\mathrm{FH}}$ generation [18] and, interestingly, both IL-6 and IL12 are potent inducers of IL-21 expression in mice [19] and humans, respectively [15]. As IL-21 is an autocrine cytokine for pre- $\mathrm{T}_{\mathrm{FH}}$ generation, further studies are required to better clarify individual cytokine contributions. Cytokine signaling involves the subsequent activation of Janus kinase-STAT (Signal Transducer and Activator of Transcription) signaling pathway. STAT3 is a major signaling molecule for IL-6 and IL-21 [20, 21], whereas IL-12 signaling occurs through STAT4 activation. However, IL-12-induced expression of IL21 by human $\mathrm{CD} 4^{+} \mathrm{T}$ cells is compromised in patients with functional STAT3 deficiency, suggesting that IL-12 ability to promote IL-21-producing $\mathrm{CD}^{+} \mathrm{T}$ cells is predominantly STAT3 dependent [22]. Moreover, STAT3-deficient patients have reduced numbers of circulating $\mathrm{T}_{\mathrm{FH}}$-like cells [23]. Altogether, these data suggest that the STAT3 signaling pathway plays an important role in $\mathrm{T}_{\mathrm{FH}}$ differentiation and subsequent B cell help.

During this first step of the $\mathrm{T}_{\mathrm{FH}}$ differentiation process, both cell surface interactions and cytokine signaling play a crucial role in $\mathrm{Bcl} 6$ induction. Bcl6 requirement for $\mathrm{T}_{\mathrm{FH}}$ development was reported in 2009 by 3 independent groups [24-26]. Indeed, Bcl6 is a master regulator for $\mathrm{T}_{\mathrm{FH}}$ lineage commitment as its expression can inhibit Th1, Th2, and Th17 differentiation [26]. Bcl6 expression is influenced by IL-6 and IL-21 via STAT1 and STAT3 signaling and by ICOSPI3K (PhosphoInositide 3-Kinase) signaling. Moreover, Bcl6 expression is controlled by a complex regulatory network of activating factors (see [7] for detailed review) such as basic leucine zipper transcriptional factor ATF like (BATF; [27]), transcription factor 1 (TCF-1; [28]), lymphoid enhancerbinding factor (LEF-1; [28]), and B cell Oct-binding protein 1 (Bobl; [29]), while forkhead box protein O1 (FOXO1; [30]) negatively regulates $\mathrm{Bcl} 6$ expression.

\subsection{Pre- $T_{F H}$ Migration to the T-B Border and $T_{F H}$ Matura-} tion: B Cells Enter the Scene. Thanks to CXCR5 expression enhancement and CCR7 downregulation (Table 2), pre$\mathrm{T}_{\mathrm{FH}}$ cells migrate to the $\mathrm{B}$ cell follicle in response to a CXCL13 gradient and their interaction with antigen-specific $\mathrm{B}$ cells at the T-B border contributes to final $\mathrm{T}_{\mathrm{FH}}$ differentiation. Indeed, the lower frequency of $\mathrm{T}_{\mathrm{FH}}$ cells in $\mathrm{B}$ celldeficient mice suggests that $\mathrm{B}$ cells are also important for the generation of $\mathrm{T}_{\mathrm{FH}}$ cells [24]. At this stage, B cells act 


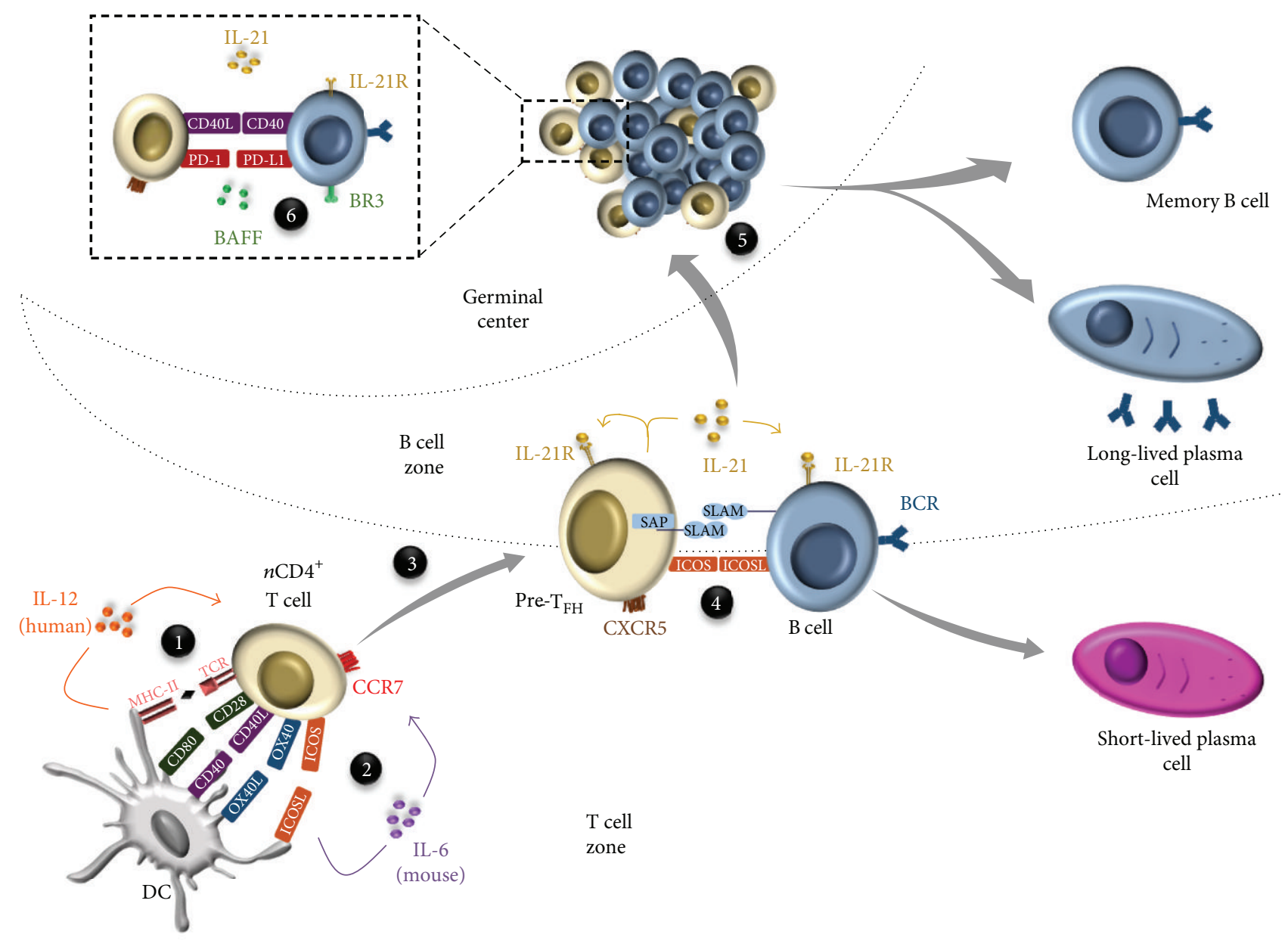

FIGURE 1: $\mathrm{T}_{\mathrm{FH}}$ differentiation in secondary lymphoid organs is a multistep process required to establish a high affinity antibody response. (1) Naive CD4 ${ }^{+} \mathrm{T}$ cells localized in the T cell zone are first primed by DC thanks to MHCII-peptide-TCR interactions. (2) Once activated, $\mathrm{CD}^{+}{ }^{+} \mathrm{T}$ cells upregulate costimulatory molecules such as CD40L, OX40, and ICOS, favoring their crosstalk with DC. Combined with this interaction DC-derived cytokines (IL-6 in mice and IL-12 in humans) drive differentiation of activated T cell into pre- $\mathrm{T}_{\mathrm{FH}}$ cells. (3) Thanks to CXCR5 upregulation and CCR7 downregulation, pre- $\mathrm{T}_{\mathrm{FH}}$ cells are attracted to the T-B border by a CXCL13 gradient. (4) A SAP/SLAMstabilized interaction between ICOSL-expressing $\mathrm{B}$ cells and pre- $\mathrm{T}_{\mathrm{FH}}$ cells occurs at the T-B border, finalizing $\mathrm{T}_{\mathrm{FH}}$ cell differentiation. (5) Finally, mature $\mathrm{T}_{\mathrm{FH}}$ cells migrate toward the $\mathrm{GC}$, where they provide help to $\mathrm{B}$ cells. This crosstalk induces both $\mathrm{B}$ cell differentiation in plasma cells and memory B cells, thanks to IL-21/IL-21R and CD40/CD40L signals, and B cell survival via BAFF/BR3 and PD1/PD-L1 interactions (6).

as the major antigen-presenting cells (APC) for primed- $\mathrm{T}_{\mathrm{FH}}$ that will then fully differentiate into GC $\mathrm{T}_{\mathrm{FH}}$ cells. Mature $\mathrm{T}_{\mathrm{FH}}$ and $\mathrm{B}$ cells that have formed stable $\mathrm{T}-\mathrm{B}$ conjugates move together into the follicle to form GC [31]. Stable T$\mathrm{B}$ conjugate formation requires interaction between ICOS on $\mathrm{T}_{\mathrm{FH}}$ and ICOSL expressed by $\mathrm{B}$ cells, as well as SLAM interactions (Table 2). SLAM are transmembrane receptors expressed on both $\mathrm{T}_{\mathrm{FH}}$ and $\mathrm{B}$ cells. SAP, which is the adaptor signaling protein downstream of SLAM, was demonstrated to be important for stabilizing cognate T-B interactions. Indeed, SAP-deficient $\mathrm{CD}^{+} \mathrm{T}$ cells have an impaired capacity to stably interact with cognate B cells, resulting in a failure to induce B cell clonal expansion [32]. Moreover, patients with X-linked Lymphoproliferative disease (XLP), an immunodeficiency resulting from mutations in the SH2D1A gene which encodes SAP, harbor humoral defects characterized by hypogammaglobulinemia and reduced numbers of $\mathrm{T}_{\mathrm{FH}}$ [33]. $\mathrm{B}$ cells thus play a key role in the $\mathrm{T}_{\mathrm{FH}}$ maturation step by both acting as APC and stabilizing $\mathrm{T}_{\mathrm{FH}}-\mathrm{GC} \mathrm{B}$ cell interactions through ICOSL and SLAM.

2.3. $T_{F H}$ Function: The Final Act of the Story. The major function of $\mathrm{T}_{\mathrm{FH}}$ is to enhance high affinity memory $\mathrm{Ab}$ responses following migration to $\mathrm{GC}$. In the follicles, $\mathrm{T}_{\mathrm{FH}^{-}}$ GC B cell crosstalk involves CD40L, IL-21, PD-1, and BAFF (B cell Activating Factor) (Table 3). The signal delivered through interaction between $\mathrm{PD}-1$ on $\mathrm{T}_{\mathrm{FH}}$ and $\mathrm{PD}-\mathrm{L} 1$ expressed by GC $B$ cells is crucial for GC B cell survival [34]. IL-21 production by $\mathrm{T}_{\mathrm{FH}}$ directly regulates $\mathrm{B}$ cell proliferation and classswitch, and the IL-21 pathway has been identified as a critical 
TABLE 1: Function of $\mathrm{T}_{\mathrm{FH}}$-related molecules during $\mathrm{T}_{\mathrm{FH}}$ differentiation.

\begin{tabular}{|c|c|c|c|}
\hline $\begin{array}{l}\mathrm{T} \text { cell } \\
\text { molecule }\end{array}$ & Ligand & Function in mice & Function in humans \\
\hline CD28 & $\mathrm{CD} 80 / 86$ & $\mathrm{CD} 28^{-/-}$mice fail to form GC $[10]$ & ND \\
\hline CD40L & $\mathrm{CD} 40$ & $\begin{array}{l}\text { T cell accumulation in B cell follicles relies on } \\
\text { CD40-dependent maturation of DC [11] }\end{array}$ & ND \\
\hline OX40 & OX40L & $\begin{array}{c}\text { T cells do not migrate to B cell follicles in } \\
\text { immunized OX40 }{ }^{-/-} \text {mice }[11] \\
\text { OX40L instructs CD } 4^{+} \mathrm{T} \text { cells to express CXCR5 } \\
{[130]} \\
\text { CD28 } 8^{-/-} \mathrm{T} \text { cells fail to upregulate OX40 }[10] \\
\text { OX40-OX40L interaction allows CD } 4^{+} \mathrm{T} \text { cells to } \\
\text { accumulate in B cell follicles }[131]\end{array}$ & $\begin{array}{c}\text { OX40 signal promotes } \mathrm{CD} 4^{+} \mathrm{T} \text { cells to express } \\
\mathrm{T}_{\mathrm{FH}} \text { molecules and to become functional B cell } \\
\text { helpers [84] }\end{array}$ \\
\hline ICOS & ICOSL & $\begin{array}{l}\text { ICOS provides a critical early signal to induce } \\
\text { Bcl6 [12] } \\
\text { Generation of } \mathrm{T}_{\mathrm{FH}} \text { depends on the PI3K signaling } \\
\text { initiated by ICOS [132] }\end{array}$ & $\begin{array}{l}\text { LOF mutations in ICOS reduce } \mathrm{cT}_{\mathrm{FH}} \text { frequencies } \\
\qquad[133]\end{array}$ \\
\hline IL6R & IL-6 & $\begin{array}{l}\text { IL-6 promotes the differentiation of naive T cells } \\
\text { in helper B cells [14] } \\
\text { IL- } 6^{-/-} \text {mice harbor reduced Bcl6 expression and } \\
\mathrm{T}_{\mathrm{FH}} \text { differentiation }[134]\end{array}$ & $\begin{array}{l}\text { Plasmablasts-derived IL-6 induces } \mathrm{T}_{\mathrm{FH}} \\
\text { differentiation [17] }\end{array}$ \\
\hline IL-12R & IL-12 & 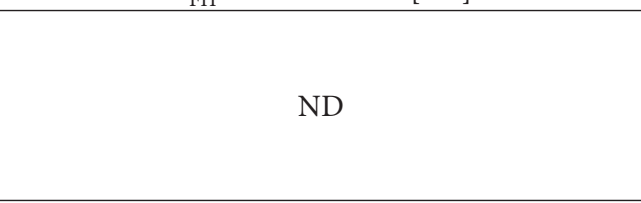 & $\begin{array}{c}\text { IL-12 induces CD4 } 4^{+} \mathrm{T} \text { cells to become } \\
\text { IL-21-producing } \mathrm{T}_{\mathrm{FH}} \text {-like cells [15] } \\
\text { IL-12 induces naive CD } 4^{+} \mathrm{T} \text { cells to acquire } \mathrm{T}_{\mathrm{FH}} \\
\text { characteristics and the ability to provide } \mathrm{B} \text { cell } \\
\text { help [16] }\end{array}$ \\
\hline IL-21R & IL-21 & $\begin{array}{l}\text { T cells activated by IL-21 acquire } \mathrm{T}_{\mathrm{FH}} \text { gene } \\
\text { expression and function [18] } \\
{\mathrm{IL}-21^{-/-}}^{\text {mice have reduced } \mathrm{T}_{\mathrm{FH}} \text { differentiation }} \\
\text { and GC formation [134] }\end{array}$ & $\begin{array}{c}\text { LOF mutations in IL-21R skewed } \mathrm{T}_{\mathrm{FH}} \\
\text { differentiation toward an IFN } \gamma^{+} \mathrm{PDI}^{+} \text {phenotype } \\
{[133]}\end{array}$ \\
\hline
\end{tabular}

GC: germinal center; DC: dendritic cells; $\mathrm{ND}$ : not determined; $\mathrm{LOF}$ : loss of function; $\mathrm{cT}_{\mathrm{FH}}$ : circulating $\mathrm{T}_{\mathrm{FH}}$; PC: plasma cells.

TABLE 2: Function of $\mathrm{T}_{\mathrm{FH}}$-related molecules during $\mathrm{T}_{\mathrm{FH}}$ migration and interaction at the $\mathrm{T} / \mathrm{B}$ border.

\begin{tabular}{|c|c|c|c|}
\hline $\begin{array}{l}\mathrm{T} \text { cell } \\
\text { molecule }\end{array}$ & Ligand & Function in mice & Function in humans \\
\hline CXCR5 & CXCL13 & $\begin{array}{l}\text { CXCR5 induction is necessary for T cell } \\
\text { homing to the follicles [135] }\end{array}$ & $\begin{array}{l}\text { T cells localized into B cell follicles express } \\
\text { CXCR5 and provide B cell help }[136,137]\end{array}$ \\
\hline CCR7 & CCL19/CCL20 & $\begin{array}{l}\text { Maintenance of CCR7 expression impedes the } \\
\text { entry of T cells on the follicles [135] }\end{array}$ & $\begin{array}{c}\text { CXCR } 5^{+} \mathrm{CD}^{+} \text {T cells loose CCR7 expression } \\
\text { in SLO }[136,137]\end{array}$ \\
\hline ICOS & ICOSL & $\begin{array}{l}\mathrm{CD}^{+} \mathrm{T} \text { cells fail to develop in } \mathrm{T}_{\mathrm{FH}} \text { and to } \\
\text { promote optimal GC responses when follicular } \\
\text { B cells do not express ICOSL [75] }\end{array}$ & 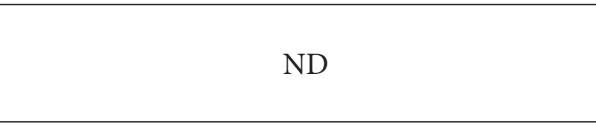 \\
\hline SAP & SLAM & $\begin{array}{l}\mathrm{CD}^{+} \mathrm{T} \text { cells from } \mathrm{SAP}^{-/-} \text {mice are unable to } \\
\text { stably interact with cognate B cells [32] }\end{array}$ & $\begin{array}{l}\text { XLP patients display reduced } \mathrm{T}_{\mathrm{FH}} \text { numbers and } \\
\text { no mem B cells }[33]\end{array}$ \\
\hline
\end{tabular}

GC: germinal center; SLO; second lymphoid organs; XLP: X-linked lymphoproliferative disease; ND: not determined; mem B cells: memory B cells.

component of the memory $\mathrm{B}$ cell response as secondary antigen-specific IgG responses are impaired in IL-21Rknockout mice [35]. BAFF is a cytokine that belongs to the Tumor Necrosis Factor (TNF) ligand family and its receptors are BCMA (B cell maturation antigen), TACI (Transmembrane Activator and Calcium modulator and Cyclophilin ligand Interactor), and BAFF Receptor 3 (BR3). BAFF is produced by stromal cells in the SLO and involved during GC development by influencing ICOSL expression on B cells and thus regulating the ability of GC $\mathrm{B}$ cells to promote $\mathrm{T}_{\mathrm{FH}}$ expansion [36]. Moreover, BAFF production by $\mathrm{T}_{\mathrm{FH}}$ is critical for the survival of high affinity B cell clones [37].

In summary, molecules that have been described to play a key role in $\mathrm{T}_{\mathrm{FH}}$ biology do not display equivalent functions. Some are necessary for $\mathrm{T}_{\mathrm{FH}}$ migration from the $\mathrm{T}$ cell zone to the GC, others are absolutely required for their development or function, and finally some of them are essential for $\mathrm{T}_{\mathrm{FH}}$ maintenance and survival (Tables 1-3). 
TABLE 3: Function of $\mathrm{T}_{\mathrm{FH}}$-related molecules during $\mathrm{B}$ cell help, $\mathrm{T}_{\mathrm{FH}}$ maintenance, and regulation.

\begin{tabular}{|c|c|c|c|}
\hline T cell molecule & Ligand & Function in mice & Function in humans \\
\hline CD40L & $\mathrm{CD} 40$ & $\begin{array}{l}\text { The formation of GC and the generation of } \\
\text { mem B cells is inhibited in the absence of } \\
\text { CD40L [138] }\end{array}$ & $\begin{array}{l}\text { CD40-CD40L interaction is required for the } \\
\text { survival of GC B cells [71] }\end{array}$ \\
\hline ICOS & ICOSL & $\mathrm{T}_{\mathrm{FH}}$ are lost in the absence of $\mathrm{B}$ cells [12] & $\begin{array}{l}\text { Patients with LOF mutation in ICOS have } \\
\text { reduced numbers of mem B cells [133] }\end{array}$ \\
\hline $\mathrm{CD} 28$ & CD80 & $\begin{array}{l}\text { CD80 expression on follicular B cells and its } \\
\text { interaction with CD28 on T cells is essential for } \\
\text { maintenance of the } \mathrm{T}_{\mathrm{FH}} \text { phenotype [139] }\end{array}$ & ND \\
\hline IL-21 & IL-21R & $\begin{array}{l}\text { IL-21 promotes the differentiation of B cells to } \\
\text { mem B cells and PC [52] } \\
\text { Mem B cells and PC fail to expand following } \\
\text { immunization in IL } 21^{-/-} \text {mice [35] }\end{array}$ & $\begin{array}{l}\text { B cell differentiation by tonsillar CXCR } 5^{+} \mathrm{T} \text { cells } \\
\text { is mediated by IL-21 [140] }\end{array}$ \\
\hline $\mathrm{IL}-4$ & IL-4R & $\begin{array}{l}\mathrm{GC} \mathrm{T}_{\mathrm{FH}} \text { cells produce IL-4, which is required } \\
\text { for optimal B cell help }[141,142]\end{array}$ & ND \\
\hline BAFF & BR3/TACI/BCMA & $\begin{array}{c}\mathrm{TACI}^{-/-} \text {mice have reduced numbers of PC due } \\
\text { to a failure in downregulating Bim [36] } \\
\mathrm{GC}_{\mathrm{FH}} \text { produce BAFF and T-cell restricted } \\
\text { BAFF deficiency impairs affinity maturation } \\
{[37]}\end{array}$ & ND \\
\hline PD-1 & PD-L1/PD-L2 & $\begin{array}{l}\text { GC B cell survival is decreased in the absence } \\
\text { of PD-1 [143] }\end{array}$ & $\begin{array}{c}{\text { CXCR } 5{ }^{+} \text {PD }-1^{\text {high }}}^{\text {T cells promote antibody }} \\
\text { responses [67] }\end{array}$ \\
\hline BTLA & HVEM & $\begin{array}{l}\text { Numbers of IL-21-producing } \mathrm{T}_{\mathrm{FH}} \text {-like cells are } \\
\text { increased in } \text { BTLA }^{-/-} \text {mice [39] }\end{array}$ & ( \\
\hline SAP & SLAM & $\begin{array}{c}\text { IL-4 production by SLAM }{ }^{-/-} \mathrm{T}_{\mathrm{FH}} \text { cells is } \\
\text { markedly reduced [142] }\end{array}$ & ND \\
\hline
\end{tabular}

GC: germinal center; ND: not determined; LOF: loss of function; mem B cells: memory B cells; PC: plasma cells.

2.4. $T_{F H}$ Regulation. Considering the important role of $\mathrm{T}_{\mathrm{FH}}$ cells in humoral immunity, a balance between stimulatory and inhibitory mechanisms regulating their function is required for immune homeostasis. However, while signals important for $\mathrm{T}_{\mathrm{FH}}$ development are clearly defined nowadays, little is known about mechanisms involved in their regulation. The coinhibitory PD-1/PD-L1 pathway can limit $\mathrm{T}_{\mathrm{FH}}$ expansion and consequently the humoral Ig response [38]. Similarly, it was demonstrated that the inhibitory receptor B and T Lymphocyte Attenuator (BTLA) suppresses GC B cell development and subsequent IgG responses by inhibiting IL-21 production by $\mathrm{T}_{\mathrm{FH}}$ cells [39] (Table 3). Recently, the existence of regulatory $\mathrm{T}$ cells (Treg) able to inhibit GC responses was described. This subset of regulatory $\mathrm{T}$ cells of thymic origin was first identified in mice [40] and named $\mathrm{T}_{\mathrm{FR}}$ (follicular regulatory $\mathrm{T}$ cells). They express typical markers of both $\mathrm{T}_{\mathrm{FH}}$ cells (Bcl6, CXCR5, PD-1, and ICOS) and classical Treg (Foxp3); they localize in the GC and possess suppressive activity. A CD4 ${ }^{+} \mathrm{T}$ cell population coexpressing Foxp3, Bcl6, and CXCR5 was also visualized in human tonsils [41].

Moreover, microRNA have recently emerged as potent regulators of $\mathrm{T}_{\mathrm{FH}}$ differentiation. Indeed, the miR-17 92 cluster was shown to promote $\mathrm{T}_{\mathrm{FH}}$ differentiation by repressing PTEN (Phosphatase and TEnsin homolg), PHLPP2 (Pleckstrin Homology domain and Leucine-rich repeat Protein Phosphatase) (phosphatases that inhibit Bcl6 expression through interfering with PI $3 \mathrm{~K}$ signaling), and ROR $\alpha$
(Retinoic acid-related Orphan Receptor $\alpha$ ) expression [42, 43]. On the other hand, miR-10a negatively regulates $\mathrm{T}_{\mathrm{FH}}$ differentiation by directly inhibiting Bcl6 expression [44]. Similarly, miR-146a, a microRNA that is highly expressed in $\mathrm{T}_{\mathrm{FH}}$ cells, was recently described as a negative regulator of $\mathrm{T}_{\mathrm{FH}}$ cell numbers [45]. miR-146a deficiency leads to accumulation of both $\mathrm{T}_{\mathrm{FH}}$ and GC B cells, likely due to enhanced ICOSL and ICOS expression on GC B cells and $\mathrm{T}_{\mathrm{FH}}$ cells, respectively [45].

Finally, IL-2 signaling is also an important negative regulator of $\mathrm{T}_{\mathrm{FH}}$ differentiation by inducing STAT5-dependent expression of Blimp1, a Bcl6 repressor [46-48]. Moreover, high IL-2 production by Th1 cells induces T-bet, which in turn inhibits Bcl6 expression and $\mathrm{T}_{\mathrm{FH}}$ differentiation [49].

\section{Evidences Supporting the Involvement of $\mathbf{T}_{\mathrm{FH}}$ in Systemic Lupus Erythematosus (SLE)}

The main function of $\mathrm{T}_{\mathrm{FH}}$ cells consists in regulating the clonal selection of GC B cells and providing B cells with signals for Ig production, isotype switching, and somatic hypermutations. As abnormal activation of $\mathrm{B}$ cells and auto $\mathrm{Ab}$ production are central to autoimmune diseases, such as lupus, altered $\mathrm{T}_{\mathrm{FH}}$ differentiation, function, and regulation were suspected to play a role in lupus pathogenesis. First hypotheses regarding the role of $\mathrm{T}_{\mathrm{FH}}$ cells in SLE development are based on studies using mice deficient for Roquin1 (a negative regulator of ICOS mRNA stability) in which an 
excessive number of $\mathrm{T}_{\mathrm{FH}}$ cells and GC reactions and high levels of IL-21 are associated with a lupus-like phenotype $[50,51]$. Other evidences come from studies on IL-21, the main cytokine produced by $\mathrm{T}_{\mathrm{FH}}$, in lupus mice. High IL21mRNA as well as elevated IL-21 serum levels were described in BXSB.Yaa mice, which develop an SLE-like disease [52]. The use of a fusion protein consisting in the IL-21R linked to the Fc domain of a mouse IgG2a (IL-21R.Fc, which therefore binds to IL-21 and prevents activation of its receptor) revealed a complex biphasic role of IL-21 in this mouse model as it increases or diminishes the disease severity depending of the stage of the disease at the time of IL-21 neutralization (at early or late stages). This could be related to the action of IL-21 on B cells but also on T cell responses [53]. In lupus MRL/lpr mice, activated $\mathrm{CD}^{+}{ }^{+} \mathrm{T}$ cells secrete 10 times more IL-21 than control mice [54] and IL-21R deficiency leads to reduced numbers of $\mathrm{T}_{\mathrm{FH}}$ cells [55]. In addition, abundant $\mathrm{T}_{\mathrm{FH}}$-like cells are located outside the $\mathrm{GC}$ where they support extrafollicular B cell differentiation and plasmablast maturation in BXSB-Yaa and MRL-Fas ${ }^{\mathrm{lpr}}$ lupus mice [56, 57]. In the latter and contrary to what was expected, the extrafollicular pathway was shown to be the most important way to generate hypermutated autoAbs [58]. However, there is no evidence to date supporting the involvement of such extrafollicular response in human SLE.

$\mathrm{T}_{\mathrm{FH}}$ cells are located in SLO; therefore the major problem encountered in studies of human $\mathrm{T}_{\mathrm{FH}}$ is that lymphoid tissues of lupus patients cannot be easily accessed, making it difficult to identify $\mathrm{T}_{\mathrm{FH}}$ cells and to determine whether the generation or function of these cells is dysregulated. First studies were based on the enumeration of $\mathrm{CD}^{+} \mathrm{CXCR}^{+}$ in peripheral blood as $\mathrm{GC} \mathrm{T}_{\mathrm{FH}}$ counterparts. Using this strategy, it was shown in human SLE that circulating $\mathrm{T}_{\mathrm{FH}}$ cells $\left(\mathrm{cT}_{\mathrm{FH}}\right)$ defined as $\mathrm{CD}^{+} \mathrm{CXCR}^{+} \mathrm{PD}-1^{+/ \text {high }}$ and/or ICOS ${ }^{+}$ $\mathrm{T}$ lymphocytes are expanded in lupus patients and their presence correlates with a more severe disease phenotype [59-64]. Recent studies have more rigorously characterized peripheral $\mathrm{CXCR} 5^{+} \mathrm{CD} 4^{+} \mathrm{T}$ cells. Morita et al. have described a circulating population in healthy donors that shares common phenotypic and functional characteristics with $\mathrm{T}_{\mathrm{FH}}$ cells from GC [65]. The authors named it $\mathrm{T}_{\mathrm{FH}}$-like cells. Moreover, they distinguished three subclasses, that is, $\mathrm{T}_{\mathrm{FH}} 17$, $\mathrm{T}_{\mathrm{FH}} 2$, and $\mathrm{T}_{\mathrm{FH}} 1$, defined according to the expression of the CCR6 and CXCR3 chemokine receptors: $\mathrm{T}_{\mathrm{FH}} 17$ cells are $\mathrm{CXCR}^{-}{ }^{-} \mathrm{CCR} 6^{+}$cells whereas $\mathrm{T}_{\mathrm{FH}} 2$ cells are $\mathrm{CXCR}^{-}{ }^{-} \mathrm{CCR} 6^{-}$ cells and $\mathrm{T}_{\mathrm{FH}} 1$ cells are $\mathrm{CXCR}^{+}{ }^{+} \mathrm{CCR} 6^{-}$cells. $\mathrm{T}_{\mathrm{FH}} 17$ and $\mathrm{T}_{\mathrm{FH}} 2$ cells were identified as able to provide help to $\mathrm{B}$ cells via IL-21 production, resulting in IgM and IgG secretion, whereas $\mathrm{T}_{\mathrm{FH}} 1$ have limited helper functions. However, ICOS expressing $\mathrm{T}_{\mathrm{FH}} 1$ are able to help memory $\mathrm{B}$ cells (but not naive $\mathrm{B}$ cells) to produce $\mathrm{Ab}$ following influenza vaccination [66]. Moreover, Morita and colleagues showed that patients with juvenile dermatomyositis displayed a profound skewing of $\mathrm{cT}_{\mathrm{FH}}$ cells towards $\mathrm{T}_{\mathrm{FH}} 2$ and $\mathrm{T}_{\mathrm{FH}} 17$ cells that correlated with disease activity, suggesting that an altered balance of $\mathrm{T}_{\mathrm{FH}}$ subtypes contributes to human autoimmunity [65]. Recently, the differential expression of ICOS, PD-1, and CCR7 interestingly allowed distinguishing three memory $\mathrm{cT}_{\mathrm{FH}}$ subsets defined as activated cells $\left(\mathrm{ICOS}^{+} \mathrm{PD} 1^{\text {hi }} \mathrm{CCR} 7^{\text {lo }}\right)$ or quiescent cells $\left(\mathrm{ICOS}^{-} \mathrm{PDI}^{+} \mathrm{CCR}^{\text {int }}\right.$ and $\left.\mathrm{ICOS}^{-} \mathrm{PDI}^{-} \mathrm{CCR}^{\mathrm{hi}}\right)[67,68]$. In SLE patients, the frequency of $\mathrm{CCR}^{\mathrm{lo}} \mathrm{PD}{ }^{\text {hi }} \mathrm{CXCR}^{+} \mathrm{CD}^{+}$ $\mathrm{T}$ cells is significantly higher than in healthy individuals [67]. The CCR $7^{\text {lo }} \mathrm{PD} 1^{\text {hi }}$ subset is indicative of active $\mathrm{T}_{\mathrm{FH}}$ differentiation and its overrepresentation is associated with elevated autoAb titers and high disease activity [67]. By analyzing CXCR 3 and CCR6 expression, we also interestingly described an altered phenotype of $\mathrm{cT}_{\mathrm{FH}}$ cells characterized by the enhanced frequency of $\mathrm{B}$ cell helper $\mathrm{T}_{\mathrm{FH}}{ }^{2-}$ like CXCR $3^{-} \mathrm{CCR}^{-}$cells and a decreased frequency of $\mathrm{CXCR}^{+}{ }^{+} \mathrm{CCR}^{-} \mathrm{T}_{\mathrm{FH}}$ 1-like cells (not able to provide $\mathrm{B}$ cell help) in lupus patients with an active disease [69].

\section{Molecules and/or Cytokines Involved in $\mathbf{T}_{\mathrm{FH}}$ Generation/Regulation Are Associated with Lupus Pathogenesis}

Aberrant expression and/or function of $\mathrm{T}_{\mathrm{FH}}$-related molecules are associated with lupus-like disease in mice $[54,70]$. Similarly, in lupus patients, numbers of molecules involved in $\mathrm{T}_{\mathrm{FH}}$ generation and/or regulation have been described to be dysregulated.

4.1. Surface Molecules. CD40/CD40L pathway plays an essential role in the initial phase of $\mathrm{T}_{\mathrm{FH}}$ development (T-DC interaction in the $\mathrm{T}$ cell zone; Figure 1, [11]) and function $\left(\mathrm{T}_{\mathrm{FH}}-\mathrm{GC} \mathrm{B}\right.$ cell crosstalk in the GC; [71]). Interestingly, CD40L was found to be constitutively expressed at abnormally high levels on $\mathrm{T}$ cells (but also on B cells and monocytes) from lupus patients $[72,73]$. Furthermore, $\mathrm{CD}^{+} \mathrm{T}$ cells from female lupus patients, which overexpressed CD40L mRNA, were able to promote autologous B cell stimulation and autoAb production [74].

ICOS-mediated PI3K signaling is absolutely required for $\mathrm{T}_{\mathrm{FH}}$ differentiation, for $\mathrm{T}_{\mathrm{FH}}$ migration into the follicle [75], and also for $\mathrm{T}_{\mathrm{FH}}$ maintenance [76]. PTEN acts as a negative regulator of the PI3K signaling pathway, leading to the inhibition of $\mathrm{Bcl} 6$ expression and $\mathrm{T}_{\mathrm{FH}}$ differentiation. Interestingly, PTEN expression is significantly decreased in SLE B cells [77]; however, to the best of our knowledge, its expression in lupus $\mathrm{CD}^{+} \mathrm{T}$ cells (especially $\mathrm{T}_{\mathrm{FH}}$ ) has not been investigated yet. ICOS expression has been found to be enhanced in $\mathrm{CD} 4^{+} \mathrm{T}$ cells from lupus patients compared to healthy donors $[78,79]$ and ICOS levels were higher in patients with nephritis than in those without nephritis [80]. Moreover, infiltrated $\mathrm{ICOS}^{+} \mathrm{T}$ cells were shown to be in close contact with B cells in lupus kidneys [79].

Interaction between OX40L (on DC) and OX40 (on activated $\mathrm{CD} 4^{+} \mathrm{T}$ cells) is also important for $\mathrm{T}_{\mathrm{FH}}$ development. OX40 expression by lupus peripheral blood cells was found to be predominantly restricted to memory $\mathrm{CD} 45 \mathrm{RO}^{+} \mathrm{CD} 4^{+}$ $\mathrm{T}$ cells and its levels correlated with disease activity [81]. Moreover, OX40 has also been found to be highly expressed in kidneys of patients with lupus nephritis [82]. Importantly, the upstream region of the OX40 gene contains a single risk haplotype for SLE, which is correlated with increased expression of OX40 mRNA and protein [83]. Finally, it was 
recently shown that OX40 signal promotes, ex vivo, the generation of $\mathrm{T}_{\mathrm{FH}}$-like cells that are functional $\mathrm{B}$ cell helpers [84].

4.2. Cytokines. Cytokine signals are absolutely required for $\mathrm{T}_{\mathrm{FH}}$ differentiation. Elevated levels of IL-6 have been found in the serum and in the urine of active SLE patients [85-87]. The increased frequency of IL-6-producing peripheral blood mononuclear cells (PBMC) correlates with disease severity/activity and treatment response [88]. Raised expression of gp130 (one of the two subunits of the IL- 6 receptor) has been found on $\mathrm{CD} 4^{+} \mathrm{T}$ cells and $\mathrm{B}$ cells from patients with active SLE, while an important reduction in the gp130 expression by $\mathrm{B}$ lymphocytes was observed upon immunosuppressive treatment leading to milder disease activity [89]. Factors responsible for the constitutive expression of IL-6 in SLE have not been elucidated yet.

Serum IL-21 levels were found to be elevated in patients with SLE $[69,90]$, especially in patients with lupus nephritis, and to correlate with disease severity [90]. The real-time PCR analysis of skin biopsies taken from 3 lupus patients also revealed that IL-21 transcripts were significantly increased compared to control individuals [91]. Furthermore, the percentages of $\mathrm{CD}^{+}{ }^{+} \mathrm{T}$ cells producing IL-21 are significantly enhanced in lupus patients [92]. Finally, polymorphisms within the IL-21R and the IL-21 genes have been reported and may confer risk for SLE: a polymorphism in IL-21R (namely, rs3093301) was found to associate with lupus in 2 independent cohorts [93], a genetic association of two SNPs located in intronic regions of the IL-21 gene (rs2221903 and rs907715) was described [94], and the variant allele rs2055979A of the IL-21 gene was recently found to be associated with increased IL-21 levels [95].

Regarding BAFF, lupus sera have been shown to contain elevated levels of this cytokine and those levels correlate with both anti-dsDNA titers [96-98] and disease activity [99]. Finally, it has been reported that IL-2 production (which inhibits $\mathrm{T}_{\mathrm{FH}}$ differentiation) upon TCR stimulation is impaired in SLE T lymphocytes [100, 101]. This lower IL2 production could be explained by imbalanced expression between the transcription factors cAMP response element (CRE) binding protein (CREB) and the CRE-modulator (CREM), which, respectively, enhance and suppress the IL2 gene transcription [102].

4.3. Transcription Factors, miRNA, and Regulatory T Cells. STAT3, which is activated by cytokines such as IL-6 and IL21, binds to the Bcl6 promoter leading to high levels of Bcl6 expression and is thus important for $\mathrm{T}_{\mathrm{FH}}$ differentiation. $\mathrm{T}$ cells from patients with SLE display increased levels of total and phosphorylated STAT3 $[103,104]$.

Reduced expression of miR-146a (a negative regulator of $\mathrm{T}_{\mathrm{FH}}$ development) has been reported in PBMC from SLE patients [105] and seems to correlate with disease activity [105]. Moreover, a genome-wide association study has highlighted a variant, that is, rs2431697, in an intergenic region between PTTG1 (Pituitary Tumor-Transforming 1) and miR146a, associated with lupus susceptibility [106]. Interestingly, the risk allele of this SNP correlates with a diminution of miR146a levels [107].

To date, the analysis of frequency and/or functionality of $\mathrm{T}_{\mathrm{FR}}$ cells in an autoimmune context has not been reported. However, although there may be some discrepancies due to variations in phenotype analysis, peripheral regulatory $\mathrm{T}$ cells $\left(\mathrm{CD} 4^{+} \mathrm{CD} 25^{+} \mathrm{T}\right.$ cells) seem to play a role in human lupus pathogenesis. Several studies reported that a decreased number of Treg might contribute to the pathogenesis [108111], but there were conflicting data regarding Treg function in lupus patients. The in vitro suppressive activity of these cells was found to be defective in some reports $[111,112]$ but other studies showed that the suppressive activity of highly purified Treg from lupus patients is not altered. It has been proposed that defective suppression in lupus could be attributed either to a higher sensitivity of Treg to Fas-mediated apoptosis in an SLE context [108] or to a lower susceptibility of effector T cells to Treg suppression [113]. Finally, it has been shown that IFN$\alpha$ production by lupus APCs might be responsible for altered Treg functionality [114].

\section{Targeting $\mathbf{T}_{\mathrm{FH}}$ : From Lupus Mice to Lupus Patients}

Data obtained from various lupus mouse models have already highlighted how blockade of signaling pathways involved in $\mathrm{T}_{\mathrm{FH}}$ generation could lead to disease improvement. The administration of a blocking ICOS-L specific monoclonal $\mathrm{Ab}(\mathrm{mAb})$ to lupus $\mathrm{NZB} / \mathrm{W}$ mice interrupted $\mathrm{T}_{\mathrm{FH}}$ cell development leading to a decrease of autoAb levels and glomerulonephritis $[115,116]$. Similar results were obtained in MRL/lpr lupus mice displaying a genetic deletion of ICOS [57].

Blockade of the CD40L-CD40 signaling pathway also led to the reduction of lupus symptoms in different mouse models [117, 118]. Treatment of MRL/lpr lupus mice with a neutralizing anti-IL-6R mAb has favorable effects on renal function and leads to a reduction of anti-dsDNA Ab levels [119]. In NZB/W mice, chronic administration of anti-IL6 or anti-IL-6R mAb improves survival and reduces the progression of proteinuria and anti-dsDNA levels [120, 121]. In lupus-prone $\mathrm{NZB} / \mathrm{W}$ and $\mathrm{MRL} / \mathrm{lpr}$ mice, raised levels of BAFF are detected at the onset of the disease [122] and treatment with either TACI-Ig or BR3-Ig is effective at preventing clinical disease and ameliorating renal injury [123]. Regarding IL-21, its neutralization using IL-21R.Fc showed an improvement of biological and clinical signs of the disease in MRL/lpr lupus mice and BXSB-Yaa mice [53, 54]. Moreover, the administration of Ab specific for the IL-21R to MRL/lpr mice significantly reduced anti-dsDNA Ab titers and IgG deposits in the kidneys when compared to control mice [124]. In NZB/W mice, such IL-21R blocking even allowed reversing nephritis and halting disease progression in mice with preexisting lupus [125]. By using a miRNA-delivery approach via bacteriophage MS2 virus-like particles, Pan and colleagues recently showed that restoring the loss of miR-146a was effective in abolishing autoAb production and delaying SLE progression in lupus-prone mice [126]. Interestingly 


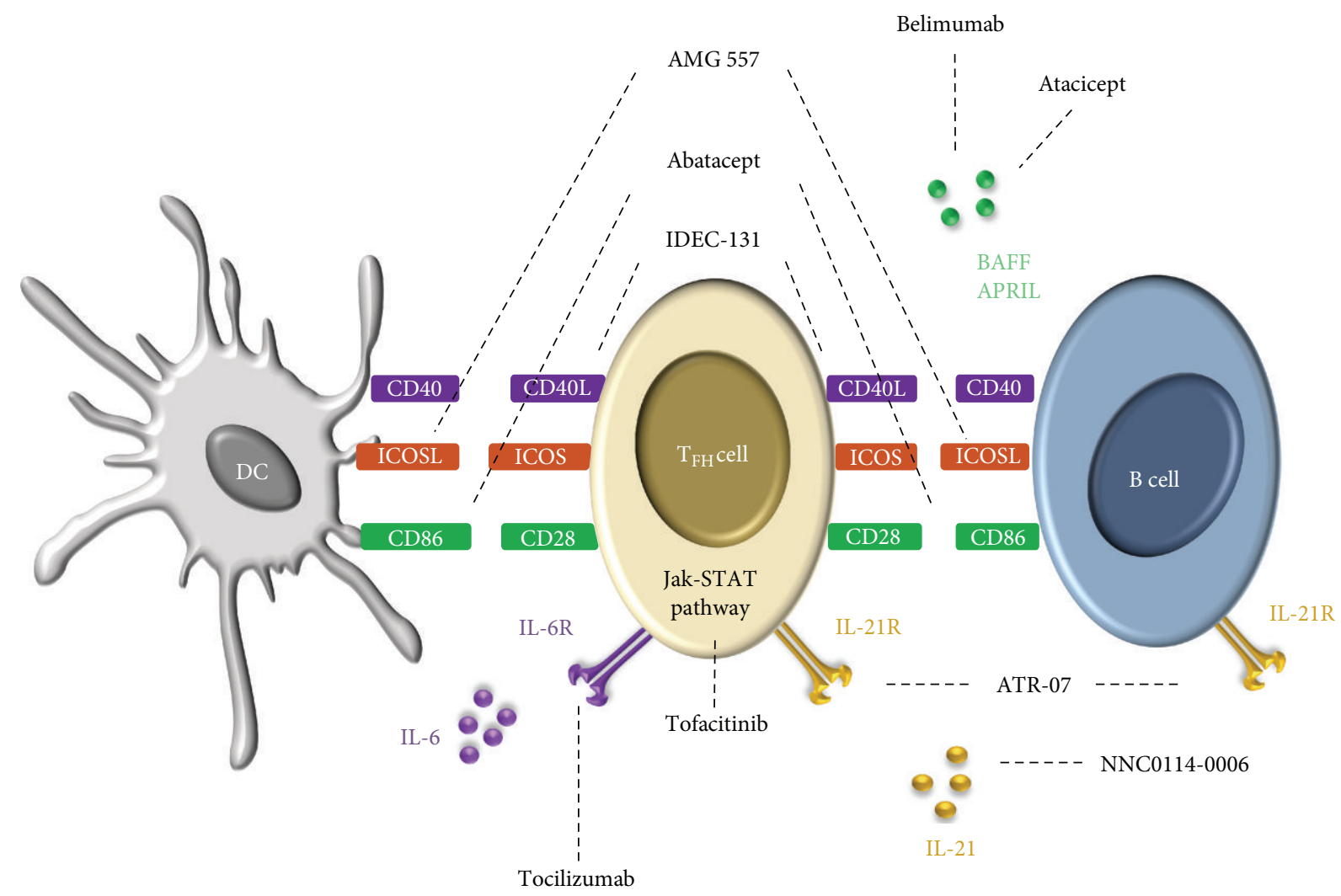

FIGURE 2: Therapeutic $\mathrm{T}_{\mathrm{FH}}$-related targets in SLE: present and future. $\mathrm{T}_{\mathrm{FH}}$ function and differentiation can be affected by several biological drugs already used in SLE therapies or currently in clinical trials. Belimumab, Atacicept, and NNC0114-0006 are mAbs targeting the soluble molecules BAFF, APRIL, and IL-21, respectively. Moreover, the blocking of T cell costimulatory molecules with AMG-557 (ICOSL), Abatacept (CD28), and IDEC-131 (CD40L) could modulate $\mathrm{T}_{\mathrm{FH}}$ differentiation by decreasing the strength of T-B interactions. Finally, promising therapies could consist in inhibiting $\mathrm{T}_{\mathrm{FH}}$ differentiation by blocking their signaling pathways either directly with the Jak-STAT inhibitor Tofacitinib or indirectly by the blockade of cytokine receptors such as IL-6R (Tocilizumab) or IL-21R (ATR-07).

also, treatment with the small molecule called Stattic (an inhibitor initially reported to block the phosphorylation, dimerization, and nuclear translocation of STAT3 in tumor cells) delayed the onset of proteinuria and reduced both antidsDNA auto Ab and inflammatory cytokine levels in MRL/lpr lupus mice [127].

There is growing evidence of $\mathrm{T}_{\mathrm{FH}}$ involvement in the pathogenesis of human SLE. Several therapeutic tools targeting $\mathrm{T}_{\mathrm{FH}}$ biology already exist and even if their direct effect on $\mathrm{T}_{\mathrm{FH}}$ development has not been evaluated, some of them were shown to improve the disease. Tocilizumab, a humanized mAb specific for the $\alpha$-chain of the IL- 6 receptor (which prevents IL-6 from binding to membrane bound and soluble IL-6 receptors), has been recently tested in SLE patients with promising results [128]. Interestingly, Tocilizumab therapy in rheumatoid arthritis patients leads to a significant reduction in circulating $\mathrm{T}_{\mathrm{FH}}$ cell numbers and IL-21 production [17]. Belimumab, a human mAb that binds soluble BAFF, therefore inhibiting recognition by BAFF specific receptors has been tested in patients and results from phase III clinical trials have demonstrated the safety profile and efficacy in controlling lupus in a broad range of patients [129]. Belimumab is the first biologic to meet its primary endpoint in a phase III clinical trial for lupus patients and it was approved by the US Food and Drug Administration in 2011. Among other potential therapeutic candidates, are those targeting T-B interactions, such as IDEC-131 (anti-CD40L Ab), AMG 557 (anti-ICOSL Ab), Abatacept (CTLA4-Ig), or targeting cytokines such as ATR-07 (anti-IL-21R Ab), NNC0114-0006 (anti-IL-21 Ab), Atacicept (TACI-Ig), and small molecules inhibiting cytokine signaling pathways (Tofacitinib, a JakSTAT inhibitor) (Figure 2).

\section{Concluding Remarks}

Although prognosis in SLE has improved markedly in the last 40 years, a better knowledge of the disease remains of prime importance to develop more potent and specific treatments. New targeted therapies designed to block pathways involved in disease pathogenesis are on the horizon. One promising option could be to specifically target factors involved in the generation of plasma cells responsible for the production of pathogenic autoAb in lupus. $\mathrm{T}_{\mathrm{FH}}$ play a critical role in $B$ cell activation and differentiation, and recent data have evidenced their involvement in lupus pathogenesis. Signals required for $\mathrm{T}_{\mathrm{FH}}$ development may thus represent interesting targets in order to reduce $\mathrm{T}_{\mathrm{FH}}$ numbers (and/or to correct the altered proportion of $\mathrm{T}_{\mathrm{FH}}$ subsets) or to qualitatively 
and/or quantitatively modulate their function. Another exciting therapeutic option consists in enhancing the negative molecular and cellular regulators of $\mathrm{T}_{\mathrm{FH}}$, such as miRNA or $\mathrm{T}_{\mathrm{FR}}$.

\section{Competing Interests}

The authors declare that they have no competing interests.

\section{Acknowledgments}

This study was supported by the French Centre National de la Recherche Scientifique (CNRS) and by a grant from the Fondation Athritis-Courtin.

\section{References}

[1] M. R. Arbuckle, M. T. McClain, M. V. Rubertone et al., "Development of autoantibodies before the clinical onset of systemic lupus erythematosus," The New England Journal of Medicine, vol. 349, no. 16, pp. 1526-1533, 2003.

[2] S. Lacotte, H. Dumortier, M. Décossas, J.-P. Briand, and S. Muller, "Identification of new pathogenic players in lupus: autoantibody-secreting cells are present in nephritic kidneys of (NZBxNZW)F1 mice," The Journal of Immunology, vol. 184, no. 7, pp. 3937-3945, 2010.

[3] E. Arce, D. G. Jackson, M. A. Gill, L. B. Bennett, J. Banchereau, and V. Pascual, "Increased frequency of pre-germinal center b cells and plasma cell precursors in the blood of children with systemic lupus erythematosus," The Journal of Immunology, vol. 167, no. 4, pp. 2361-2369, 2001.

[4] A. M. Jacobi, M. Odendahl, K. Reiter et al., "Correlation between circulating CD27high plasma cells and disease activity in patients with systemic lupus erythematosus," Arthritis \& Rheumatism, vol. 48, no. 5, pp. 1332-1342, 2003.

[5] C. T. Ravirajan, M. A. Rahman, L. Papadaki et al., "Genetic, structural and functional properties of an IgG DNA-binding monoclonal antibody from a lupus patient with nephritis," European Journal of Immunology, vol. 28, no. 1, pp. 339-350, 1998.

[6] A. C. Grammer, R. Slota, R. Fischer et al., "Abnormal germinal center reactions in systemic lupus erythematosus demonstrated by blockade of CD154-CD40 interactions," The Journal of Clinical Investigation, vol. 112, no. 10, pp. 1506-1520, 2003.

[7] C. G. Vinuesa, M. A. Linterman, D. Yu, and I. C. M. MacLennan, "Follicular helper T cells," Annual Review of Immunology, vol. 34, pp. 335-368, 2016.

[8] S. Crotty, "Follicular helper CD4 T cells (TFH)," Annual Review of Immunology, vol. 29, pp. 621-663, 2011.

[9] N. Fazilleau, L. J. McHeyzer-Williams, H. Rosen, and M. G. McHeyzer-Williams, "The function of follicular helper T cells is regulated by the strength of T cell antigen receptor binding," Nature Immunology, vol. 10, no. 4, pp. 375-384, 2009.

[10] L. S. K. Walker, A. Gulbranson-Judge, S. Flynn et al., "Compromised OX40 function in CD28-deficient mice is linked with failure to develop CXC chemokine receptor 5-positive CD4 cells and germinal centers," The Journal of Experimental Medicine, vol. 190, no. 8, pp. 1115-1122, 1999.

[11] S. Fillatreau and D. Gray, "T cell accumulation in B cell follicles is regulated by dendritic cells and is independent of B cell activation," Journal of Experimental Medicine, vol. 197, no. 2, pp. 195-206, 2003.

[12] Y. S. Choi, R. Kageyama, D. Eto et al., "ICOS receptor instructs $\mathrm{T}$ follicular helper cell versus effector cell differentiation via induction of the transcriptional repressor Bcl6," Immunity, vol. 34, no. 6, pp. 932-946, 2011.

[13] X. Liu, X. Chen, B. Zhong et al., "Transcription factor achaetescute homologue 2 initiates follicular T-helper-cell development," Nature, vol. 507, no. 7493, pp. 513-518, 2014.

[14] F. Eddahri, S. Denanglaire, F. Bureau et al., "Interleukin6/STAT3 signaling regulates the ability of naive T cells to acquire B-cell help capacities," Blood, vol. 113, no. 11, pp. 2426-2433, 2009.

[15] N. Schmitt, R. Morita, L. Bourdery et al., "Human dendritic cells induce the differentiation of interleukin-21-producing $\mathrm{T}$ follicular helper-like cells through interleukin-12," Immunity, vol. 31, no. 1, pp. 158-169, 2009.

[16] C. S. Ma, S. Suryani, D. T. Avery et al., "Early commitment of naïve human $\mathrm{CD}^{+} \mathrm{T}$ cells to the $\mathrm{T}$ follicular helper $\left(\mathrm{T}_{\mathrm{FH}}\right)$ cell lineage is induced by IL-12," Immunology and Cell Biology, vol. 87, no. 8, pp. 590-600, 2009.

[17] K.-M. Chavele, E. Merry, and M. R. Ehrenstein, "Circulating plasmablasts induce the differentiation of human $\mathrm{T}$ follicular helper cells via IL-6 production," Journal of Immunology, vol. 194, no. 6, pp. 2482-2485, 2015.

[18] R. I. Nurieva, Y. Chung, D. Hwang et al., "Generation of $\mathrm{T}$ follicular helper cells is mediated by interleukin-21 but independent of T helper 1, 2, or 17 cell lineages," Immunity, vol. 29, no. 1, pp. 138-149, 2008.

[19] O. Dienz, S. M. Eaton, J. P. Bond et al., "The induction of antibody production by IL- 6 is indirectly mediated by IL21 produced by $\mathrm{CD}^{+} \mathrm{T}$ cells," The Journal of Experimental Medicine, vol. 206, no. 1, pp. 69-78, 2009.

[20] R. Spolski and W. J. Leonard, "Interleukin-21: basic biology and implications for cancer and autoimmunity," Annual Review of Immunology, vol. 26, pp. 57-79, 2008.

[21] P. C. Heinrich, I. Behrmann, S. Haan, H. M. Hermanns, G. Müller-Newen, and F. Schaper, "Principles of interleukin (IL)-6-type cytokine signalling and its regulation," Biochemical Journal, vol. 374, no. 1, pp. 1-20, 2003.

[22] C. S. Ma, D. T. Avery, A. Chan et al., "Functional STAT3 deficiency compromises the generation of human $\mathrm{T}$ follicular helper cells," Blood, vol. 119, no. 17, pp. 3997-4008, 2012.

[23] F. Mazerolles, C. Picard, S. Kracker, A. Fischer, and A. Durandy, "Blood $\mathrm{CD}^{+}{ }^{+} \mathrm{CD} 45 \mathrm{RO}^{+} \mathrm{CXCR}^{+} \mathrm{T}$ cells are decreased but partially functional in signal transducer and activator of transcription 3 deficiency," The Journal of Allergy and Clinical Immunology, vol. 131, no. 4, pp. 1146-1156, 2013.

[24] R. J. Johnston, A. C. Poholek, D. DiToro et al., "Bcl6 and Blimp-1 are reciprocal and antagonistic regulators of $\mathrm{T}$ follicular helper cell differentiation," Science, vol. 325, no. 5943, pp. 1006-1010, 2009.

[25] R. I. Nurieva, Y. Chung, G. J. Martinez et al., "Bcl6 mediates the development of T follicular helper cells," Science, vol. 325, no. 5943, pp. 1001-1005, 2009.

[26] D. Yu, S. Rao, L. M. Tsai et al., "The transcriptional repressor Bcl-6 directs $\mathrm{T}$ follicular helper cell lineage commitment," Immunity, vol. 31, no. 3, pp. 457-468, 2009.

[27] B. C. Betz, K. L. Jordan-Williams, C. Wang et al., "Batf coordinates multiple aspects of $\mathrm{B}$ and $\mathrm{T}$ cell function required for normal antibody responses," Journal of Experimental Medicine, vol. 207, no. 5, pp. 933-942, 2010. 
[28] Y. S. Choi, J. A. Gullicksrud, S. Xing et al., "LEF-1 and TCF-1 orchestrate $\mathrm{T}(\mathrm{HF})$ differentiation by regulating differentiation circuits upstream of the transcriptional repressor Bcl6," Nature Immunology, vol. 16, no. 9, pp. 980-990, 2015.

[29] D. Stauss, C. Brunner, F. Berberich-Siebelt, U. E. Ho pken, M. Lipp, and G. Mu ller, "The transcriptional coactivator Bobl promotes the development of follicular T helper cells via Bcl6," The EMBO Journal, vol. 35, no. 8, pp. 881-898, 2016.

[30] E. L. Stone, M. Pepper, C. D. Katayama et al., "ICOS coreceptor signaling inactivates the transcription factor FOXO1 to promote Tfh cell differentiation," Immunity, vol. 42, no. 2, pp. 239-251, 2015.

[31] S. M. Kerfoot, G. Yaari, J. R. Patel et al., "Germinal center B cell and $\mathrm{T}$ follicular helper cell development initiates in the interfollicular zone," Immunity, vol. 34, no. 6, pp. 947-960, 2011.

[32] H. Qi, J. L. Cannons, F. Klauschen, P. L. Schwartzberg, and R. N. Germain, "SAP-controlled T-B cell interactions underlie germinal centre formation," Nature, vol. 455, no. 7214, pp. 764$769,2008$.

[33] C. S. Ma, N. J. Hare, K. E. Nichols et al., "Impaired humoral immunity in X-linked lymphoproliferative disease is associated with defective IL-10 production by CD4+ T cells," Journal of Clinical Investigation, vol. 115, no. 4, pp. 1049-1059, 2005.

[34] L. V. Riella, A. M. Paterson, A. H. Sharpe, and A. Chandraker, "Role of the PD-1 pathway in the immune response," American Journal of Transplantation, vol. 12, no. 10, pp. 2575-2587, 2012.

[35] A. L. Rankin, H. MacLeod, S. Keegan et al., "IL-21 receptor is critical for the development of memory B cell responses," Journal of Immunology, vol. 186, no. 2, pp. 667-674, 2011.

[36] X. Ou, S. Xu, and K.-P. Lam, "Deficiency in TNFRSF13B (TACI) expands T-follicular helper and germinal center B cells via increased ICOS-ligand expression but impairs plasma cell survival," Proceedings of the National Academy of Sciences of the United States of America, vol. 109, no. 38, pp. 15401-15406, 2012.

[37] R. Goenka, A. H. Matthews, B. Zhang et al., "Local BLyS production by $\mathrm{T}$ follicular cells mediates retention of high affinity B cells during affinity maturation," The Journal of Experimental Medicine, vol. 211, no. 1, pp. 45-56, 2014.

[38] E. Hams, M. J. McCarron, S. Amu et al., "Blockade of B7-H1 (programmed death ligand 1) enhances humoral immunity by positively regulating the generation of $\mathrm{T}$ follicular helper cells," The Journal of Immunology, vol. 186, no. 10, pp. 5648-5655, 2011.

[39] D. Kashiwakuma, A. Suto, Y. Hiramatsu et al., "B and T lymphocyte attenuator suppresses IL-21 production from follicular Th cells and subsequent humoral immune responses," The Journal of Immunology, vol. 185, no. 5, pp. 2730-2736, 2010.

[40] M. A. Linterman, W. Pierson, S. K. Lee et al., "Foxp3+ follicular regulatory T cells control the germinal center response," Nature Medicine, vol. 17, no. 8, pp. 975-982, 2011.

[41] Y. Chung, S. Tanaka, F. Chu et al., "Follicular regulatory T cells expressing Foxp3 and Bcl-6 suppress germinal center reactions," Nature Medicine, vol. 17, no. 8, pp. 983-988, 2011.

[42] S. G. Kang, W.-H. Liu, P. Lu et al., "MicroRNAs of the miR-17 92 family are critical regulators of TFH differentiation," Nature Immunology, vol. 14, no. 8, pp. 849-857, 2013.

[43] D. Baumjohann, R. Kageyama, J. M. Clingan et al., "The microRNA cluster miR-17 92 promotes TFH cell differentiation and represses subset-inappropriate gene expression," Nature Immunology, vol. 14, no. 8, pp. 840-848, 2013.

[44] H. Takahashi, T. Kanno, S. Nakayamada et al., "TGF- $\beta$ and retinoic acid induce the microRNA miR-10a, which targets
Bcl- 6 and constrains the plasticity of helper T cells," Nature Immunology, vol. 13, no. 6, pp. 587-595, 2012.

[45] A. Pratama, M. Srivastava, N. J. Williams et al., "MicroRNA146a regulates ICOS-ICOSL signalling to limit accumulation of $\mathrm{T}$ follicular helper cells and germinal centres," Nature Communications, vol. 6, article 6436, 2015.

[46] A. Ballesteros-Tato, B. León, B. A. Graf et al., "Interleukin2 inhibits germinal center formation by limiting $\mathrm{T}$ follicular helper cell differentiation," Immunity, vol. 36, no. 5, pp. 847-856, 2012.

[47] R. J. Johnston, Y. S. Choi, J. A. Diamond, J. A. Yang, and S. Crotty, "STAT5 is a potent negative regulator of TFH cell differentiation," Journal of Experimental Medicine, vol. 209, no. 2, pp. 243-250, 2012.

[48] R. I. Nurieva, A. Podd, Y. Chen et al., "STAT5 protein negatively regulates T follicular helper (Tfh) cell generation and function," The Journal of Biological Chemistry, vol. 287, no. 14, pp. 11234$11239,2012$.

[49] K. J. Oestreich, S. E. Mohn, and A. S. Weinmann, "Molecular mechanisms that control the expression and activity of Bcl-6 in $\mathrm{T}_{\mathrm{H}} 1$ cells to regulate flexibility with a $\mathrm{T}_{\mathrm{FH}}$-like gene profile," Nature Immunology, vol. 13, no. 4, pp. 405-411, 2012.

[50] C. G. Vinuesa, M. C. Cook, C. Angelucci et al., "A RING-type ubiquitin ligase family member required to repress follicular helper T cells and autoimmunity," Nature, vol. 435, no. 7041, pp. 452-458, 2005.

[51] M. A. Linterman, R. J. Rigby, R. K. Wong et al., "Follicular helper T cells are required for systemic autoimmunity," Journal of Experimental Medicine, vol. 206, no. 3, pp. 561-576, 2009.

[52] K. Ozaki, R. Spolski, R. Ettinger et al., "Regulation of B cell differentiation and plasma cell generation by IL-21, a novel inducer of Blimp-1 and Bcl-6," The Journal of Immunology, vol. 173, no. 9, pp. 5361-5371, 2004.

[53] J. A. Bubier, S. M. Bennett, T. J. Sproule et al., “Treatment of BXSB-Yaa mice with IL-21R-Fc fusion protein minimally attenuates systemic lupus erythematosus," Annals of the New York Academy of Sciences, vol. 1110, pp. 590-601, 2007.

[54] D. Herber, T. P. Brown, S. Liang, D. A. Young, M. Collins, and K. Dunussi-Joannopoulos, "IL-21 has a pathogenic role in a lupusprone mouse model and its blockade with IL-21R.Fc reduces disease progression," The Journal of Immunology, vol. 178, no. 6, pp. 3822-3830, 2007.

[55] A. L. Rankin, H. Guay, D. Herber et al., "IL-21 receptor is required for the systemic accumulation of activated $\mathrm{B}$ and $\mathrm{T}$ lymphocytes in MRL/MpJ-Fas lpr/lpr/J mice," Journal of Immunology, vol. 188, no. 4, pp. 1656-1667, 2012.

[56] J. A. Bubier, T. J. Sproule, O. Foreman et al., "A critical role for IL-21 receptor signaling in the pathogenesis of systemic lupus erythematosus in BXSB-Yaa mice," Proceedings of the National Academy of Sciences of the United States of America, vol. 106, no. 5, pp. 1518-1523, 2009.

[57] J. M. Odegard, B. R. Marks, L. D. Diplacido et al., "ICOSdependent extrafollicular helper $\mathrm{T}$ cells elicit IgG production via IL-21 in systemic autoimmunity," Journal of Experimental Medicine, vol. 205, no. 12, pp. 2873-2886, 2008.

[58] J. William, C. Euler, S. Christensen, and M. J. Shlomchik, "Evolution of autoantibody responses via somatic hypermutation outside of germinal centers," Science, vol. 297, no. 5589, pp. 2066-2070, 2002.

[59] N. Simpson, P. A. Gatenby, A. Wilson et al., "Expansion of circulating $\mathrm{T}$ cells resembling follicular helper $\mathrm{T}$ cells is a fixed 
phenotype that identifies a subset of severe systemic lupus erythematosus," Arthritis and Rheumatism, vol. 62, no. 1, pp. 234-244, 2010.

[60] J.-Y. Choi, J. H.-E. Ho, S. G. Pasoto et al., "Circulating follicular helper-like T cells in systemic lupus erythematosus: association with disease activity," Arthritis and Rheumatology, vol. 67, no. 4, pp. 988-999, 2015.

[61] X. Feng, D. Wang, J. Chen et al., "Inhibition of aberrant circulating Tfh cell proportions by corticosteroids in patients with systemic lupus erythematosus," PLoS ONE, vol. 7, no. 12, Article ID e51982, 2012.

[62] X. Zhang, E. Lindwall, C. Gauthier et al., "Circulating CXCR $5^{+} \mathrm{CD} 4^{+}$helper $\mathrm{T}$ cells in systemic lupus erythematosus patients share phenotypic properties with germinal center follicular helper T cells and promote antibody production," Lupus, vol. 24, no. 9, pp. 909-917, 2015.

[63] H. Xu, J. Liu, X. Cui et al., "Increased frequency of circulating follicular helper $\mathrm{T}$ cells in lupus patients is associated with autoantibody production in a CD40L-dependent manner," Cellular Immunology, vol. 295, no. 1, pp. 46-51, 2015.

[64] K. Szabó, G. Papp, A. Szántó, T. Tarr, and M. Zeher, “A comprehensive investigation on the distribution of circulating follicular T helper cells and B cell subsets in primary Sjögren's syndrome and systemic lupus erythematosus," Clinical and Experimental Immunology, vol. 183, no. 1, pp. 76-89, 2016.

[65] R. Morita, N. Schmitt, S.-E. Bentebibel et al., "Human blood $\mathrm{CXCR}^{+} \mathrm{CD}^{+} \mathrm{T}$ cells are counterparts of $\mathrm{T}$ follicular cells and contain specific subsets that differentially support antibody secretion," Immunity, vol. 34, no. 1, pp. 108-121, 2011.

[66] S. E. Bentebibel, S. Lopez, G. Obermoser et al., "Induction of $\mathrm{ICOS}^{+} \mathrm{CXCR}^{+} \mathrm{CXCR}^{+} \mathrm{TH}$ cells correlates with antibody responses to influenza vaccination," Science Translational Medicine, vol. 5, no. 7, Article ID 176ra32, 2013.

[67] J. He, L. M. Tsai, Y. Leong et al., "Circulating precursor CCR7loPD-1hi CXCR5+ CD4+ T cells indicate th cell activity and promote antibody responses upon antigen reexposure," Immunity, vol. 39, no. 4, pp. 770-781, 2013.

[68] M. Locci, C. Havenar-Daughton, E. Landais et al., "Human circulating PD-1+CXCR3-CXCR5+ memory Tfh cells are highly functional and correlate with broadly neutralizing HIV antibody responses," Immunity, vol. 39, no. 4, pp. 758-769, 2013.

[69] C. Le Coz, A. Joublin, J.-L. Pasquali, A.-S. Korganow, H. Dumortier, and F. Monneaux, "Circulating TFH subset distribution is strongly affected in lupus patients with an active disease," PLoS ONE, vol. 8, no. 9, Article ID e75319, 2013.

[70] G. C. Zeller, J. Hirahashi, A. Schwarting, A. H. Sharpe, and V. R. Kelley, "Inducible co-stimulator null MRL-Faslpr mice: uncoupling of autoantibodies and T cell responses in lupus," Journal of the American Society of Nephrology, vol. 17, no. 1, pp. 122-130, 2006.

[71] Y.-J. Liu, D. E. Joshua, G. T. Williams, C. A. Smith, J. Gordon, and I. C. M. MacLennan, "Mechanism of antigen-driven selection in germinal centres," Nature, vol. 342, no. 6252, pp. 929-931, 1989.

[72] A. Desai-Mehta, L. Lu, R. Ramsey-Goldman, and S. K. Datta, "Hyperexpression of CD40 ligand by B and T cells in human lupus and its role in pathogenic autoantibody production," Journal of Clinical Investigation, vol. 97, no. 9, pp. 2063-2073, 1996.

[73] C. G. Katsiari, S.-N. C. Liossis, A. M. Dimopoulos, D. V. Charalambopoulos, M. Mavrikakis, and P. P. Sfikakis, "CD40L overexpression on $\mathrm{T}$ cells and monocytes from patients with systemic lupus erythematosus is resistant to calcineurin inhibition," Lupus, vol. 11, no. 6, pp. 370-378, 2002.

[74] Y. Zhou, J. Yuan, Y. Pan et al., "T cell CD40LG gene expression and the production of IgG by autologous B cells in systemic lupus erythematosus," Clinical Immunology, vol. 132, no. 3, pp. 362-370, 2009.

[75] H. Xu, X. Li, D. Liu et al., "Follicular T-helper cell recruitment governed by bystander B cells and ICOS-driven motility," Nature, vol. 496, no. 7446, pp. 523-527, 2013.

[76] D. Liu, H. Xu, C. Shih et al., "T-B-cell entanglement and ICOSLdriven feed-forward regulation of germinal centre reaction," Nature, vol. 517, no. 7533, pp. 214-218, 2015.

[77] X.-N. Wu, Y.-X. Ye, J.-W. Niu et al., "Defective PTEN regulation contributes to B cell hyperresponsiveness in systemic lupus erythematosus," Science Translational Medicine, vol. 6, no. 246, Article ID 246ra99, 2014.

[78] J.-H. Yang, J. Zhang, Q. Cai et al., "Expression and function of inducible costimulator on peripheral blood $\mathrm{T}$ cells in patients with systemic lupus erythematosus," Rheumatology, vol. 44, no. 10, pp. 1245-1254, 2005.

[79] A. Hutloff, K. Büchner, K. Reiter et al., "Involvement of inducible costimulator in the exaggerated memory B cell and plasma cell generation in systemic lupus erythematosus," Arthritis and Rheumatism, vol. 50, no. 10, pp. 3211-3220, 2004.

[80] W.-X. Li, H.-F. Pan, G.-P. Chen, J.-H. Tao, X.-P. Li, and D.-Q. Ye, "Expression of inducible co-stimulator on peripheral blood T lymphocytes in patients with lupus nephritis," Rheumatology International, vol. 32, no. 7, pp. 2051-2055, 2012.

[81] S. Patschan, S. Dolff, A. Kribben et al., "CD134 expression on $\mathrm{CD} 4+\mathrm{T}$ cells is associated with nephritis and disease activity in patients with systemic lupus erythematosus," Clinical and Experimental Immunology, vol. 145, no. 2, pp. 235-242, 2006.

[82] J. Aten, A. Roos, N. Claessen, E. J. M. Schilder-Tol, I. J. M. Ten Berge, and J. J. Weening, "Strong and selective glomerular localization of CD134 ligand and TNF receptor-1 in proliferative lupus nephritis," Journal of the American Society of Nephrology, vol. 11, no. 8, pp. 1426-1438, 2000.

[83] D. S. C. Graham, R. R. Graham, H. Manku et al., "Polymorphism at the TNF superfamily gene TNFSF4 confers susceptibility to systemic lupus erythematosus," Nature Genetics, vol. 40, no. 1, pp. 83-89, 2008.

[84] C. Jacquemin, N. Schmitt, C. Contin-Bordes et al., "OX40 ligand contributes to human lupus pathogenesis by promoting T follicular helper response," Immunity, vol. 42, no. 6, pp. 11591170, 2015.

[85] H.-Y. Chun, J.-W. Chung, H.-A. Kim et al., "Cytokine IL-6 and IL-10 as biomarkers in systemic lupus erythematosus," Journal of Clinical Immunology, vol. 27, no. 5, pp. 461-466, 2007.

[86] G. Gröndal, I. Gunnarsson, J. Rönnelid, S. Rogberg, L. Klareskog, and I. Lundberg, "Cytokine production, serum levels and disease activity in systemic lupus erythematosus," Clinical and Experimental Rheumatology, vol. 18, no. 5, pp. 565-570, 2000.

[87] Y. Horii, M. Iwano, E. Hirata et al., "Role of interleukin-6 in the progression of mesangial proliferative glomerulonephritis," Kidney International, vol. 39, pp. S71-S75, 1993.

[88] P. Esposito, M. M. Balletta, A. Procino, L. Postiglione, and B. Memoli, "Interleukin-6 release from peripheral mononuclear cells is associated to disease activity and treatment response in patients with lupus nephritis," Lupus, vol. 18, no. 14, pp. 13291330, 2009. 
[89] M. De La Torre, J. M. Urra, and J. Blanco, "Raised expression of cytokine receptor gp130 subunit on peripheral lymphocytes of patients with active lupus. A useful tool for monitoring the disease activity?" Lupus, vol. 18, no. 3, pp. 216-222, 2009.

[90] X.-F. Wang, S.-L. Yuan, L. Jiang et al., "Changes of serum BAFF and IL-21 levels in patients with systemic lupus erythematosus and their clinical significance," Xi Bao Yu Fen Mian Yi Xue Za Zhi, vol. 23, no. 11, pp. 1041-1042, 2007.

[91] R. Caruso, E. Botti, M. Sarra et al., "Involvement of interleukin21 in the epidermal hyperplasia of psoriasis," Nature Medicine, vol. 15, no. 9, pp. 1013-1015, 2009.

[92] S. Dolff, W. H. Abdulahad, J. Westra et al., "Increase in IL-21 producing T-cells in patients with systemic lupus erythematosus," Arthritis Research \& Therapy, vol. 13, no. 5, article R157, 2011.

[93] R. Webb, J. T. Merrill, J. A. Kelly et al., "A polymorphism within IL21R confers risk for systemic lupus erythematosus," Arthritis and Rheumatism, vol. 60, no. 8, pp. 2402-2407, 2009.

[94] A. H. Sawalha, K. M. Kaufman, J. A. Kelly et al., "Genetic association of interleukin-21 polymorphisms with systemic lupus erythematosus," Annals of the Rheumatic Diseases, vol. 67, no. 4, pp. 458-461, 2008.

[95] Y. Lan, B. Luo, J.-L. Wang, Y.-W. Jiang, and Y.-S. Wei, “The association of interleukin-21 polymorphisms with interleukin21 serum levels and risk of systemic lupus erythematosus," Gene, vol. 538, no. 1, pp. 94-98, 2014.

[96] J. Zhang, V. Roschke, K. P. Baker et al., "Cutting edge: a role for B lymphocyte stimulator in systemic lupus erythematosus," The Journal of Immunology, vol. 166, no. 1, pp. 6-10, 2001.

[97] G. S. Cheema, V. Roschke, D. M. Hilbert, and W. Stohl, "Elevated serum B lymphocyte stimulator levels in patients with systemic immune-based rheumatic diseases," Arthritis and Rheumatism, vol. 44, no. 6, pp. 1313-1319, 2001.

[98] W. Stohl, S. Metyas, S.-M. Tan et al., "B lymphocyte stimulator overexpression in patients with systemic lupus erythematosus: longitudinal observations," Arthritis \& Rheumatism, vol. 48, no. 12, pp. 3475-3486, 2003.

[99] M. Petri, W. Stohl, W. Chatham et al., "Association of plasma B lymphocyte stimulator levels and disease activity in systemic lupus erythematosus," Arthritis and Rheumatism, vol. 58, no. 8, pp. 2453-2459, 2008.

[100] M. Linker-Israeli, A. C. Bakke, R. C. Kitridou, S. Gendler, S. Gillis, and D. A. Horwitz, "Defective production of interleukin 1 and interleukin 2 in patients with systemic lupus erythematosus (SLE)," Journal of Immunology, vol. 130, no. 6, pp. 2651-2655, 1983.

[101] L. A. Lieberman and G. C. Tsokos, "The IL-2 defect in systemic lupus erythematosus disease has an expansive effect on host immunity," Journal of Biomedicine and Biotechnology, vol. 2010, Article ID 740619, 6 pages, 2010.

[102] E. E. Solomou, Y.-T. Juang, M. F. Gourley, G. M. Kammer, and G. C. Tsokos, "Molecular basis of deficient IL-2 production in T cells from patients with systemic lupus erythematosus," The Journal of Immunology, vol. 166, no. 6, pp. 4216-4222, 2001.

[103] T. Harada, V. Kyttaris, Y. Li, Y.-T. Juang, Y. Wang, and G. C. Tsokos, "Increased expression of STAT3 in SLE T cells contributes to enhanced chemokine-mediated cell migration," Autoimmunity, vol. 40, no. 1, pp. 1-8, 2007.

[104] C. M. Hedrich, T. Rauen, S. A. Apostolidis et al., "Stat3 promotes IL-10 expression in lupus T cells through trans-activation and chromatin remodeling," Proceedings of the National Academy of Sciences of the United States of America, vol. 111, no. 37, pp. 1345713462, 2014.
[105] Y. Tang, X. Luo, H. Cui et al., "MicroRNA-146a contributes to abnormal activation of the type I interferon pathway in human lupus by targeting the key signaling proteins," Arthritis and Rheumatism, vol. 60, no. 4, pp. 1065-1075, 2009.

[106] J. B. Harley, M. E. Alarcón-Riquelme, L. A. Criswell et al., "Genome-wide association scan in women with systemic lupus erythematosus identifies susceptibility variants in ITGAM, PXK, KIAA1542 and other loci," Nature Genetics, vol. 40, no. 2, pp. 204-210, 2008.

[107] S. E. Löfgren, J. Frostegård, L. Truedsson et al., "Genetic association of miRNA-146a with systemic lupus erythematosus in Europeans through decreased expression of the gene," Genes \& Immunity, vol. 13, no. 3, pp. 268-274, 2012.

[108] M. Miyara, Z. Amoura, C. Parizot et al., "Global natural regulatory T cell depletion in active systemic lupus erythematosus," The Journal of Immunology, vol. 175, no. 12, pp. 8392-8400, 2005.

[109] M.-F. Liu, C.-R. Wang, L.-L. Fung, and C.-R. Wu, "Decreased $\mathrm{CD} 4^{+} \mathrm{CD} 25^{+} \mathrm{T}$ cells in peripheral blood of patients with systemic lupus erythematosus," Scandinavian Journal of Immunology, vol. 59, no. 2, pp. 198-202, 2004.

[110] J. C. Crispin, A. Martínez, and J. Alcocer-Varela, "Quantification of regulatory T cells in patients with systemic lupus erythematosus," Journal of Autoimmunity, vol. 21, no. 3, pp. 273-276, 2003.

[111] M. Bonelli, A. Savitskaya, K. von Dalwigk et al., "Quantitative and qualitative deficiencies of regulatory $\mathrm{T}$ cells in patients with systemic lupus erythematosus (SLE)," International Immunology, vol. 20, no. 7, pp. 861-868, 2008.

[112] X. Valencia, C. Yarboro, G. Illei, and P. E. Lipsky, "Deficient $\mathrm{CD} 4+\mathrm{CD} 25$ high $\mathrm{T}$ regulatory cell function in patients with active systemic lupus erythematosus," Journal of Immunology, vol. 178, no. 4, pp. 2579-2588, 2007.

[113] R. K. C. Venigalla, T. Tretter, S. Krienke et al., "Reduced $\mathrm{CD} 4^{+}, \mathrm{CD} 25^{-} \mathrm{T}$ cell sensitivity to the suppressive function of $\mathrm{CD}^{+}$,CD25high,CD127 /low regulatory T cells in patients with active systemic lupus erythematosus," Arthritis \& Rheumatism, vol. 58, no. 7, pp. 2120-2130, 2008.

[114] B. Yan, S. Ye, G. Chen, M. Kuang, N. Shen, and S. Chen, "Dysfunctional CD4+,CD25+ regulatory T cells in untreated active systemic lupus erythematosus secondary to interferon$\alpha$-producing antigen-presenting cells," Arthritis \& Rheumatism, vol. 58, no. 3, pp. 801-812, 2008.

[115] H. Iwai, M. Abe, S. Hirose et al., "Involvement of inducible costimulator-B7 homologous protein costimulatory pathway in murine lupus nephritis," Journal of Immunology, vol. 171, no. 6, pp. 2848-2854, 2003.

[116] Y.-L. Hu, D. P. Metz, J. Chung, G. Siu, and M. Zhang, "B7RP1 blockade ameliorates autoimmunity through regulation of follicular helper T cells," The Journal of Immunology, vol. 182, no. 3, pp. 1421-1428, 2009.

[117] J. Ma, J. Xu, M. P. Madaio et al., "Autoimmune lpr/lpr mice deficient in CD40 ligand: spontaneous Ig class switching with dichotomy of autoantibody responses," Journal of Immunology, vol. 157, no. 1, pp. 417-426, 1996.

[118] D. I. Daikh, B. K. Finck, P. S. Linsley, D. Hollenbaugh, and D. Wofsy, "Long-term inhibition of murine lupus by brief simultaneous blockade of the B7/CD28 and CD40/gp39 costimulation pathways," The Journal of Immunology, vol. 159, no. 7, pp. 31043108, 1997.

[119] B. A. Kiberd, "Interleukin-6 receptor blockage ameliorates murine lupus nephritis," Journal of the American Society of Nephrology, vol. 4, no. 1, pp. 58-61, 1993. 
[120] B. K. Finck, B. Chan, and D. Wofsy, "Interleukin 6 promotes murine lupus in NZB/NZW F1 mice," Journal of Clinical Investigation, vol. 94, no. 2, pp. 585-591, 1994.

[121] M. Mihara, N. Takagi, Y. Takeda, and Y. Ohsugi, "IL-6 receptor blockage inhibits the onset of autoimmune kidney disease in $\mathrm{NZB} / \mathrm{W} \mathrm{F}_{1}$ mice," Clinical and Experimental Immunology, vol. 112, no. 3, pp. 397-402, 1998.

[122] J. A. Gross, J. Johnston, S. Mudri et al., "TACI and BCMA are receptors for a TNF homologue implicated in B-cell autoimmune disease," Nature, vol. 404, no. 6781, pp. 995-999, 2000.

[123] M. Ramanujam, R. Bethunaickan, W. Huang, H. Tao, M. P. Madaio, and A. Davidson, "Selective blockade of BAFF for the prevention and treatment of systemic lupus erythematosus nephritis in NZM2410 mice," Arthritis and Rheumatism, vol. 62, no. 5, pp. 1457-1468, 2010.

[124] Y. Vugmeyster, H. Guay, P. Szklut et al., "In vitro potency, pharmacokinetic profiles, and pharmacological activity of optimized anti-IL-21R antibodies in a mouse model of lupus," $m A b s$, vol. 2, no. 3, pp. 335-346, 2010.

[125] M. Zhang, G. Yu, B. Chan et al., "Interleukin-21 receptor blockade inhibits secondary humoral responses and halts the progression of preestablished disease in the $(\mathrm{NZB} \times \mathrm{NZW}) \mathrm{F} 1$ systemic lupus erythematosus model," Arthritis \& Rheumatology, vol. 67, no. 10, pp. 2723-2731, 2015.

[126] Y. Pan, T. Jia, Y. Zhang et al., "MS2 VLP-based delivery of microRNA-146a inhibits autoantibody production in lupusprone mice," International Journal of Nanomedicine, vol. 7, pp. 5957-5967, 2012.

[127] L. J. Edwards, M. Mizui, and V. Kyttaris, "Signal transducer and activator of transcription (STAT) 3 inhibition delays the onset of lupus nephritis in MRL/lpr mice," Clinical Immunology, vol. 158, no. 2, pp. 221-230, 2015.

[128] G. G. Illei, Y. Shirota, C. H. Yarboro et al., "Tocilizumab in systemic lupus erythematosus: data on safety, preliminary efficacy, and impact on circulating plasma cells from an open-label phase I dosage-escalation study," Arthritis and Rheumatism, vol. 62, no. 2, pp. 542-552, 2010.

[129] S. V. Navarra, R. M. Guzmán, A. E. Gallacher et al., "Efficacy and safety of belimumab in patients with active systemic lupus erythematosus: a randomised, placebo-controlled, phase 3 trial," The Lancet, vol. 377, no. 9767, pp. 721-731, 2011.

[130] S. Flynn, K.-M. Toellner, C. Raykundalia, M. Goodall, and P. Lane, "CD4 T cell cytokine differentiation: the B cell activation molecule, OX40 ligand, instructs CD4 T cells to express interleukin 4 and upregulates expression of the chemokine receptor, Blr-1," The Journal of Experimental Medicine, vol. 188, no. 2, pp. 297-304, 1998.

[131] T. Brocker, A. Gulbranson-Judge, S. Flynn, M. Riedinger, C. Raykundalia, and P. Lane, "CD4 T cell traffic control: in vivo evidence that ligation of OX40 on CD4 T cells by OX40-ligand expressed on dendritic cells leads to the accumulation of CD4 T cells in B follicles," European Journal of Immunology, vol. 29, no. 5, pp. 1610-1616, 1999.

[132] M. Gigoux, J. Shang, Y. Pak et al., "Inducible costimulator promotes helper T-cell differentiation through phosphoinositide 3kinase," Proceedings of the National Academy of Sciences of the United States of America, vol. 106, no. 48, pp. 20371-20376, 2009.

[133] C. S. Ma, N. Wong, G. Rao et al., "Monogenic mutations differentially affect the quantity and quality of T follicular helper cells in patients with human primary immunodeficiencies," Journal of Allergy and Clinical Immunology, vol. 136, no. 4, pp. 993-1006, 2015.
[134] D. Eto, C. Lao, D. DiToro et al., "IL-21 and IL-6 are critical for different aspects of $\mathrm{B}$ cell immunity and redundantly induce optimal follicular helper CD4 T cell (Tfh) differentiation," PLoS ONE, vol. 6, no. 3, Article ID el7739, 2011.

[135] N. M. Haynes, C. D. C. Allen, R. Lesley, K. M. Ansel, N. Killeen, and J. G. Cyster, "Role of CXCR5 and CCR7 in follicular Th cell positioning and appearance of a programmed cell death gene-1High germinal center-associated subpopulation," Journal of Immunology, vol. 179, no. 8, pp. 5099-5108, 2007.

[136] D. Breitfeld, L. Ohl, E. Kremmer et al., "Follicular B helper $\mathrm{T}$ cells express CXC chemokine receptor 5, localize to B cell follicles, and support immunoglobulin production," The Journal of Experimental Medicine, vol. 192, no. 11, pp. 1545-1551, 2000.

[137] P. Schaerli, K. Willimann, A. B. Lang, M. Lipp, P. Loetscher, and B. Moser, "CXC chemokine receptor 5 expression defines follicular homing $\mathrm{T}$ cells with $\mathrm{B}$ cell helper function," The Journal of Experimental Medicine, vol. 192, no. 11, pp. 1553-1562, 2000.

[138] T. M. Foy, J. D. Laman, J. A. Ledbetter, A. Aruffo, E. Claassen, and R. J. Noelle, "gp39-CD40 interactions are essential for germinal center formation and the development of B cell memory," The Journal of Experimental Medicine, vol. 180, no. 1, pp. 157-163, 1994.

[139] S. Salek-Ardakani, Y. S. Choi, M. R.-E. Benhnia et al., "B cell-specific expression of B7-2 is required for follicular Th cell function in response to vaccinia virus," The Journal of Immunology, vol. 186, no. 9, pp. 5294-5303, 2011.

[140] V. L. Bryant, C. S. Ma, D. T. Avery et al., "Cytokine-mediated regulation of human B cell differentiation into Ig-secreting cells: predominant role of IL-21 produced by CXCR5+ T follicular helper cells," Journal of Immunology, vol. 179, no. 12, pp. 81808190, 2007.

[141] R. L. Reinhardt, H.-E. Liang, and R. M. Locksley, "Cytokinesecreting follicular T cells shape the antibody repertoire," Nature Immunology, vol. 10, no. 4, pp. 385-393, 2009.

[142] I. Yusuf, R. Kageyama, L. Monticelli et al., "Germinal center T follicular helper cell IL-4 production is dependent on signaling lymphocytic activation molecule receptor (CD150)," Journal of Immunology, vol. 185, no. 1, pp. 190-202, 2010.

[143] K. L. Good-Jacobson, C. G. Szumilas, L. Chen, A. H. Sharpe, M. M. Tomayko, and M. J. Shlomchik, "PD-1 regulates germinal center B cell survival and the formation and affinity of longlived plasma cells," Nature Immunology, vol. 11, no. 6, pp. 535$542,2010$. 


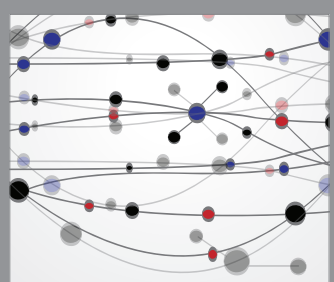

The Scientific World Journal
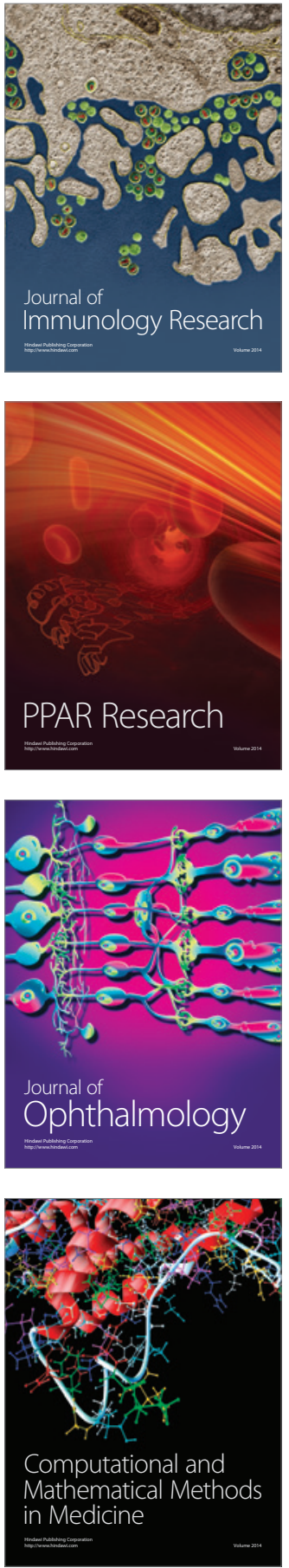

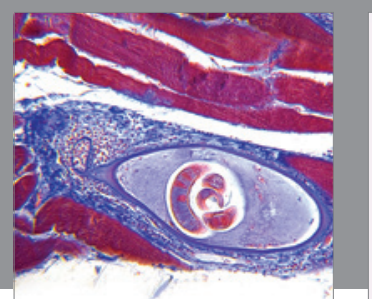

Gastroenterology Research and Practice

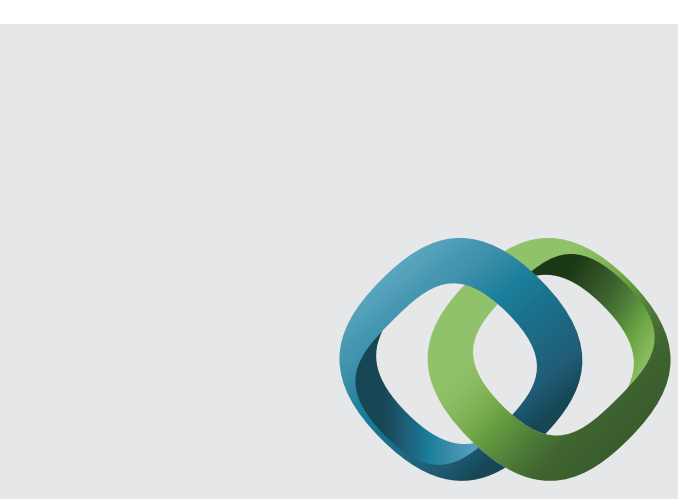

\section{Hindawi}

Submit your manuscripts at

http://www.hindawi.com
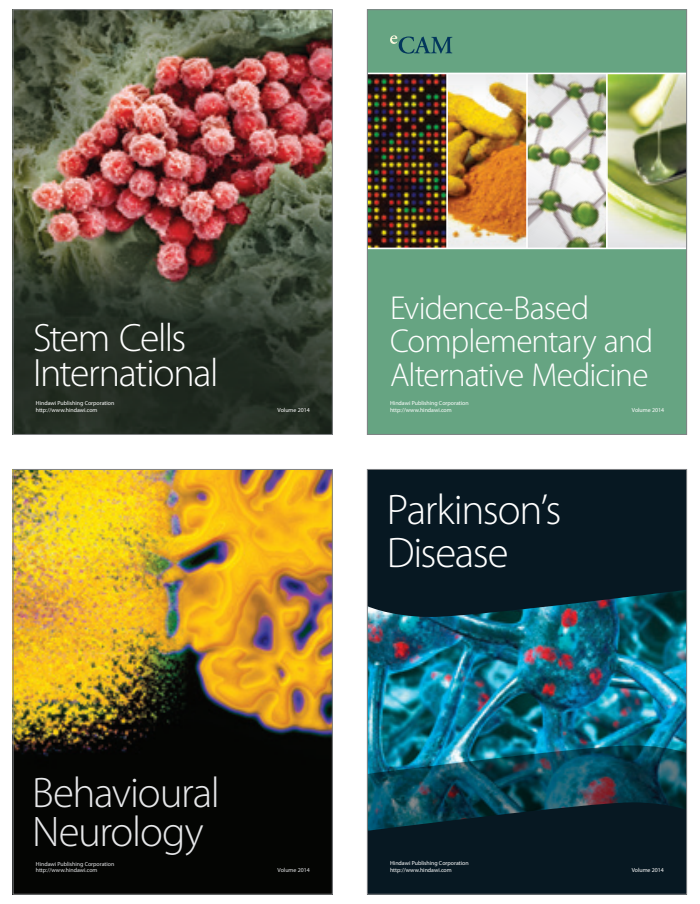
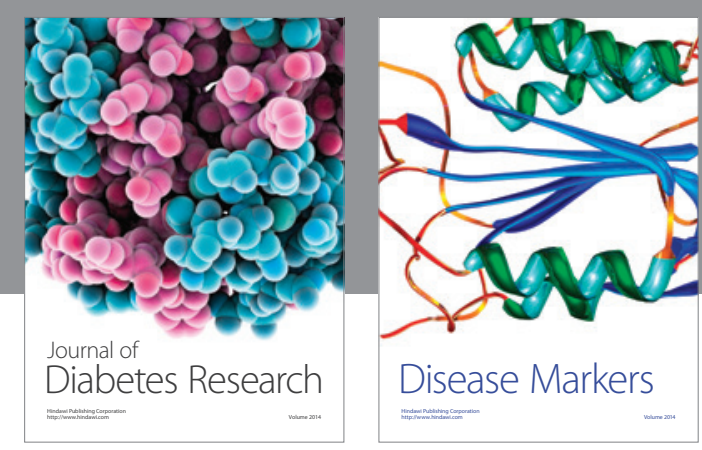

Disease Markers
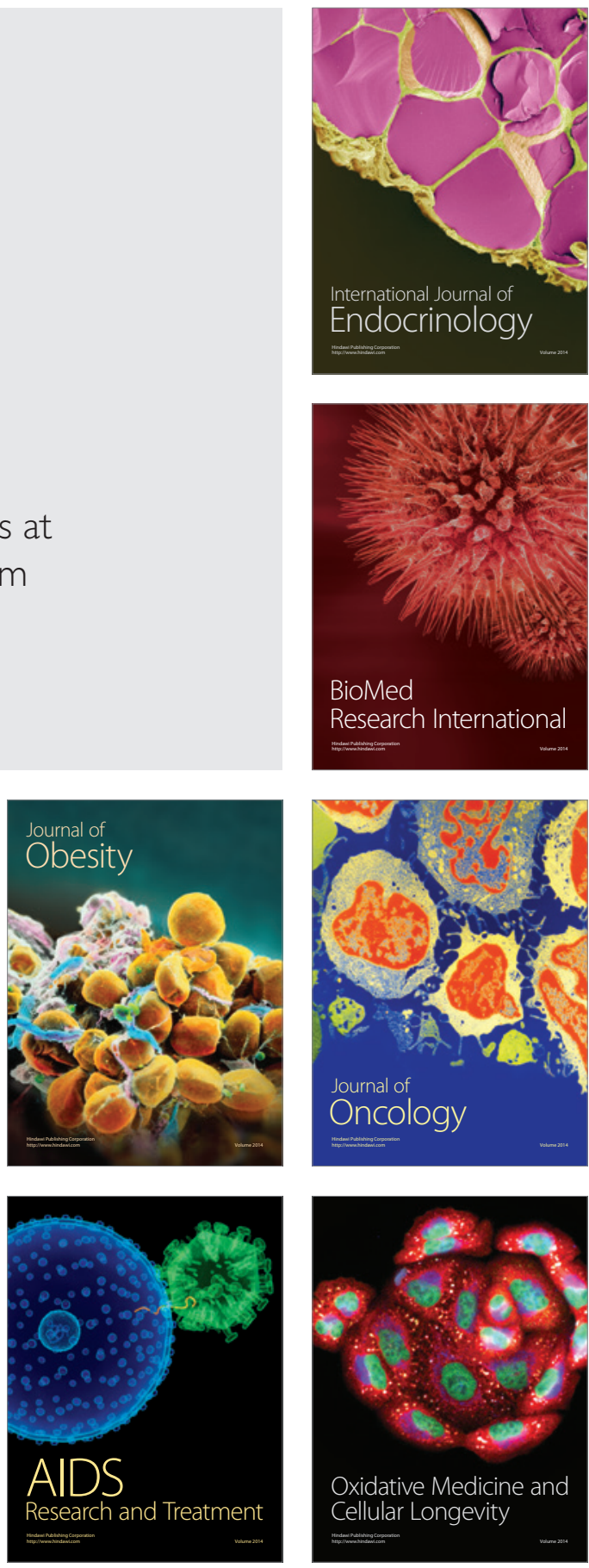